Article

\title{
A GIS-based DRASTIC Model and an Adjusted DRASTIC Model (DRASTICA) for Groundwater Susceptibility Assessment along the China-Pakistan Economic Corridor (CPEC) Route
}

\author{
Ahsen Maqsoom ${ }^{1}{ }^{1}$, Bilal Aslam ${ }^{2}\left(\mathbb{D}\right.$, Umer Khalil $^{1}$, Omid Ghorbanzadeh ${ }^{3, *} \mathbb{D}$, Hassan Ashraf ${ }^{1}$, \\ Rana Faisal Tufail ${ }^{1}$, Danish Farooq ${ }^{4}\left[\right.$ and Thomas Blaschke ${ }^{3}$ (D) \\ 1 Department of Civil Engineering, COMSATS University Islamabad, Wah Campus 47040, Pakistan; \\ ahsen.maqsoom@ciitwah.edu.pk (A.M.); umerkhalil745@gmail.com (U.K.); \\ drhassanashraf@ciitwah.edu.pk (H.A.); faisal.tufail@ciitwah.edu.pk (R.F.T.) \\ 2 Department of Earth Sciences, Quaid-i-Azam University, Islamabad 45320, Pakistan; \\ bilalaslam45@gmail.com \\ 3 Department of Geoinformatics, University of Salzburg, 5020 Salzburg, Austria; thomas.blaschke@sbg.ac.at \\ 4 Department of Transport Technology and Economics, Budapest University of Technology and Economics, \\ 1111 Budapest, Hungary; farooq.danish@mail.bme.hu \\ * Correspondence: omid.ghorbanzadeh@stud.sbg.ac.at
}

Received: 1 April 2020; Accepted: 17 May 2020; Published: 19 May 2020

check for updates

\begin{abstract}
Land use types and anthropogenic activities represent considerable threats to groundwater pollution. To effectively monitor the groundwater quality, it is vital to measure pollution levels before they become severe. In our research area, located in Gilgit Baltistan in northern Pakistan, groundwater supplies are diminishing due to urban sprawl. In this study, we used a GIS-based DRASTIC model (Depth to water, Recharge, Aquifer media, Soil media, Topography, Impact of the vadose zone, Hydraulic conductivity) to analyze the area's hydrological attributes to assess the groundwater susceptibility to pollution. Considering the importance of anthropogenic activities, this research primarily utilizes an adjusted DRASTIC model called DRASTICA, which incorporates anthropogenic impact as a parameter in the model. The resulting map, which depicts vulnerability to groundwater contamination, reveals that $19 \%$ of the study area is classed as having high vulnerability, $42 \%$ has moderate vulnerability, $37 \%$ has low vulnerability, and $2 \%$ has very low vulnerability to groundwater contamination. The adopted validation process (nitrate parameter of water quality) revealed that the suggested DRASTICA model achieved better results than the established DRASTIC model in a built-up environment. We used the nitrate concentration in groundwater to verify the formulated results, and the single parameter sensitivity analysis and map removal sensitivity analysis to analyze the model sensitivity. The sensitivity analysis indicated that the groundwater vulnerability to pollution is largely influenced by anthropogenic impact and depth to the water table, thereby suggesting that anthropogenic impact must be explicitly tackled in such studies. The groundwater zones exposed to anthropogenic pollution can be better classified with the help of the proposed DRASTICA model, particularly in and around built-up environments. The responsible authorities can use this groundwater contamination data as an early warning sign, so they can take practical actions to avoid extra pressure on this vital resource.
\end{abstract}

Keywords: groundwater vulnerability; GIS; modified DRASTIC; DRASTICA; urbanized environment 


\section{Introduction}

All societies, productions, and ecologies require a clean and abundant water supply for energy production, drinking, sanitation, and farming. The quantity and quality of groundwater are significant universal matters, and the water crisis represents a severe threat faced by human beings in the present times [1-3]. One of the most important sources of drinking water is the groundwater, as the pollutants from the surface of earth are less influential to this source. However, the quality of groundwater is increasingly threatened by human activities, leading to momentary or enduring damage to the resource. Consequently, harmful contaminants must be removed from the water before use, thus inviting a significant cost [4]. An abrupt upsurge in urban development has negatively impacted the quality and quantity of groundwater [5]. The availability of freshwater is vital for sustainable growth of the natural ecosystem and human wellbeing. Therefore, for planners and decision-makers, to comprehend an area's groundwater susceptibility to contamination is a vital process [6,7].

The most available source of potable water supply in emerging countries like Pakistan is groundwater. In Pakistan, economic growth and employment are mainly based on agriculture. A substantial portion of the gross domestic product (GDP) stems from agriculture and the associated industry [8]. In many agricultural areas, land treatment using fertilizers makes aquifers prone to nitrate contamination, which represents a severe threat to groundwater purity. Other nations, including China, India, and Bangladesh are also suffering from susceptibility to groundwater pollution. Both in India and in other parts of the world, aquifers are the foremost supplier for the water sector [9]. The investigations conducted in Bangladesh on groundwater have mostly been limited to hydrogeochemical and hydrogeological features, including groundwater quality, groundwater potential, heavy metal pollutants, and hydrogeological modeling $[4,10]$. However, groundwater contamination susceptibility dur to mining actions in an open-pit coal mine in Bangladesh was assessed by Haque, Reza [11]. In 2013, the Belt and Road (B\&R) project proposed by China, represents the Silk Road Economic Belt besides the 21st Century Maritime Silk Road. The main objectives of this initiative are devotion to collaboration and growth around the world. Pakistan is a part of this initiative, led by China, which increases the country's regional importance. In particular, the province of Gilgit Baltistan in northern Pakistan has an important location on the silk route. Presently, most B\&R countries, including China, are undergoing diverse notches of water scarcity [12,13].

The DRASTIC (Depth to water, Recharge, Aquifer media, Soil media, Topography, Impact of the vadose zone, Hydraulic conductivity) model is commonly used to assess the susceptibility of groundwater reserves to pollution [14-17]. Hydrological and geological factors control the groundwater flow into, through, and out of an aquifer. In the DRASTIC model, these factors are compositely represented as hydrogeological settings [18]. The main hydrogeological features of an area that control the groundwater susceptibility are the dwelling time of rainwater, infiltration of water past the soil, the amount of water reaching the water table, and the water flowing into the aquifer [19]. The movement of contaminants in an aquifer is controlled by seven hydrogeological parameters that are considered in the DRASTIC model [20]. The acronym of these respective parameter names generates the term 'DRASTIC', and the parameters are the depth to water, recharge of network area, aquifer matrix, soil media, topography, the impact of the vadose zone, and hydraulic conductivity [21]. Many approaches have been developed to measure aquifer susceptibility, such as index and overlay procedures, process-based procedures, and arithmetical procedures [5]. The most universally used index and overlay procedure is the DRASTIC procedure [17,22-27].

Despite its acceptance, no validation such as nitrate concentration in groundwater against field measurements has been followed in the practice of novel DRASTIC model. Besides, the originally proposed preset values by Aller [28] were configured to assign the weights to the factor, the ratings of the classes are selected based on the expert's finding, that acquaints vagueness, error, and human partiality in the process. Besides amending factor weights and ratings based on the ground measured data, two approaches are generally used to adapt the DRASTIC method: 1) removing or altering factors included in the DRASTIC model [22], or 2) adding further parameters like land use or irrigation 
type [23]. Nitrate mediation and land use design play a key role in the betterment of the DRASTIC method's precision for groundwater susceptibility assessment [5]. Shirazi and Imran [5] evaluated the groundwater susceptibility in the Malaysian State of Melaka using GIS and DRASTIC methods and developed a map to evaluate the susceptibility of groundwater based on land use. Hussain et al. [29] assessed the susceptibility of an agro-stressed aquifer in Kot Addu, the portion of grander Punjab plain, due to non-point sources of pollution, salinity, and unchecked agricultural growth in a GIS environment implementing a source-pathway-receptor model normally specified as DRASTIC. Alam et al. [30] evaluated the susceptibility of groundwater to pollution by modifying DRASTIC in the region of Central Ganga Plain by including constraints such as land use patterns. Khan et al. [31] experienced that land use patterns regulate the quantity and quality of narrow aquifer at large when they investigated the susceptibility of groundwater in the region of Indo-Gangetic Plains. Rahman [17] studied the groundwater susceptibility to pollution in a narrow aquifer of Aligarh and adjacent areas. The adjusted DRASTIC procedure was used by Ckakraborty et al. [32] to evaluate the aquifer susceptibility of the zone of West Bengal, English Bazar Block of District Malda.

Previous research assessing groundwater susceptibility to pollution reveals that the land areas of municipalities are gradually inclined to pollution [30]. On a large scale, susceptibility analyses reveal that the fundamental aquifer will be polluted or not and as if this contamination is may be due to the anthropological happenings or other than these (usual happenings). Generally, the areas where resources of water are strained due to anthropogenic occurrences are being subject to susceptibility assessments. The studies outlined above assessed the susceptibility of groundwater to pollution without considering the anthropogenic effect in the DRASTIC model. The effects of anthropology play a substantial part in the contamination of groundwater in residential areas. In the present study, we adjusted the DRASTIC model to DRASTICA, whereby the ' $\mathrm{A}$ ' represents the additional constraint of 'Influence of Anthropogenic activities'. Many other scholars, including Secunda et al., [23], Al-Adamat et al., [33], and Huan et ai., [34] also applied the additional limitation of land use in an adjusted DRASTIC model. This method was successfully applied by Singh et al., [27] in the assessment of groundwater susceptibility to pollution in a built-up setting in Lucknow, India.

In this research, we used GIS techniques to evaluate groundwater susceptibility to pollutants by applying the typical DRASTIC model, involving seven hydrogeological data layers, along with the adjusted DRASTIC model, using both designs of land use and the anthropogenic effect, for a buffer area of $30 \mathrm{~km}$ to either side of the Karakoram Highway (KKH), which is a part of the CPEC route. The CPEC route will increase the anthropogenic activities in the area, which might increase the groundwater contamination potential; hence, there is a dire need for the groundwater contamination assessment to mitigate the threat of further pollution.

\section{Materials and Methods}

\subsection{Study Area}

Gilgit district, located at one end of the study area, is the capital city of Gilgit Baltistan (geographical coordinates $35.8819^{\circ} \mathrm{N}, 74.4643^{\circ} \mathrm{E}$ ), and comprises an approximate area of $4208 \mathrm{~km}^{2}$ on each side of the Indus river (a giant river that intersects Pakistan and flows into the Arabian sea) (see Figure 1). Gilgit Baltistan is a provincial unit made up of two states-Gilgit and Baltistan-which jointly comprise ten districts. The population of Gilgit district, which is a built-up area, is 145,272 (census 1998-03-01). The weather conditions of the study area are dominated by its topography. The average annual rainfall of Gilgit city is $107.8 \mathrm{~mm}$ with the variation of four different seasons: spring, summer, autumn, and winter. The period of the winter season is comparatively greater (eight to nine months a year) due to heavy rainfall. The temperature reaches $35 \mathrm{C}^{\circ}$ during summer, from June to August, and the minimum temperature drops to $-8 \mathrm{C}^{\circ}$ during winter, between December and January. Gilgit city is the most consequential city in terms of its geographical importance. In the past, it was a central halt on the ancient Silk Road, and, today, it serves as the main intersection between China and Pakistan along the 
Karakoram Highway while CPEC (China Pakistan Economic Corridor) is in progress. The city has an elevation of 1,500 m above sea level. Gilgit Baltistan is a region that is highly susceptible to climate change. Gilgit Baltistan does not contain any industrial zones. At the other end of the study area is Bara Khun (longitude $75.1622^{\circ} \mathrm{E}$ and latitude $36.8761^{\circ} \mathrm{N}$ ) with the original pronunciation of Bāra Khūn.

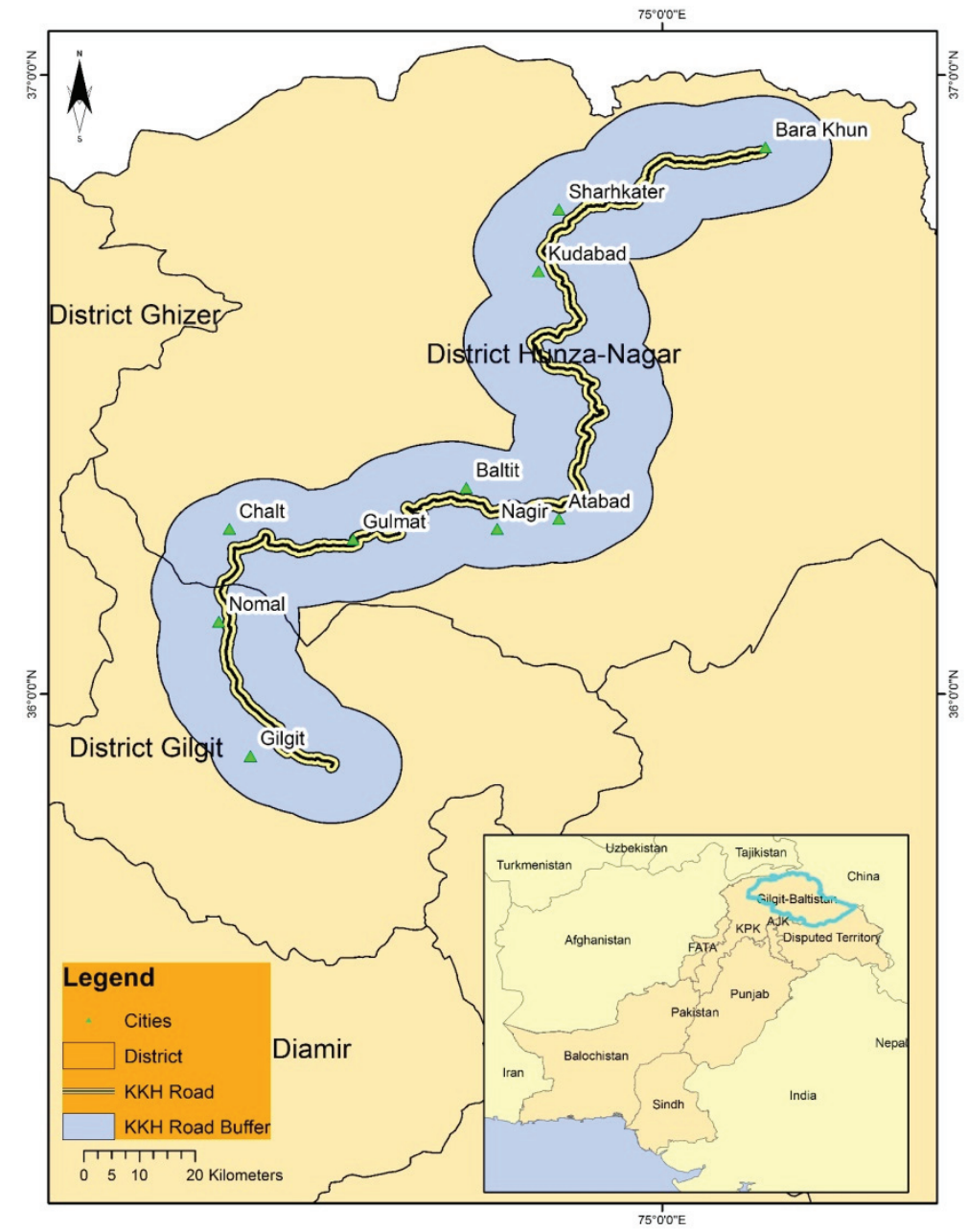

Figure 1. Location map of the study area.

\subsection{DRASTIC Model}

In the past, an overlay GIS model called DRASTIC (Depth to water, Recharge, Aquifer media, Soil media, Topography, Impact of the vadose zone, Hydraulic conductivity), was the central approach used by researchers to evaluate groundwater quality because of its unpretentious and uncomplicated nature [35]. This model has been extensively applied in nations across the globe [36].

The resulting groundwater susceptibility maps are very useful for the planning of groundwater organization and preservation. In this research, the aquifer vulnerability maps, and hydrogeological characteristic maps were prepared by exercising the DRASTIC model in ArcGIS 10.3 software. Seven parameters were considered for the formerly stated model, and the corresponding seven map layers were used as input for this model. The seven considered model parameters are Depth to groundwater-surface $(D)$, recharge rate $(R)$, aquifer matrix $(A)$, soil type $(S)$, topography $(T)$, the impact of vadose zone (I), and hydraulic conductivity (C). We used the weights and ratings of these parameters to yield a numerical index using the DRASTIC model [37,38]. The DRASTIC Index (DI) was calculated using the following equation:

$$
\mathrm{DI}=\mathrm{DrDw}+\mathrm{RrRw}+\mathrm{ArAw}+\mathrm{SrSw}+\mathrm{TrTw}+\mathrm{IrIw}+\mathrm{CrCw}
$$


where,

$\mathrm{r}=$ ratings allocated to each parameter

$\mathrm{w}=$ weights allocated to each parameter

Thereby, higher values of the DRASTIC index specify that the groundwater is more susceptible to contamination.

\subsection{Background Sources and Preparation of Input Datasets (Methodology)}

The groundwater aquifers are a source of water for the community. Considering the importance of groundwater aquifers and the sustainable use of groundwater, it is essential to assess their susceptibility to pollution. The U.S. Environmental Protection Agency used the DRASTIC model to evaluate the susceptibility of groundwater to contamination, which is a suitable approach for this purpose [39]. The zones or regions of groundwater that were more susceptible to pollution were outlined using this model.

Hydrogeological studies include determination of soil penetration proportions, valuation of aquifer parameters, sedimentary environment, and the probation of soil consistency for spotting the grain differences. To determine the rating ranges of a parameter, it is necessary to be familiar with the regional geology and hydrogeology of the investigative area. To understand the hydrogeological setting of the study area, the mapping of environmental, geological, and hydrological elements is of utmost importance. For every parameter, the practice of mapping the study area according to the DRASTIC index was explained subsequently.

The data sources for the preparation of the input parameter maps are shown in Table 1. The ArcGIS 10.3 software was used for the formulation of input datasets and for execution of the DRASTIC model. Thereby, we applied the RBF technique to the available data points and create the map layers representing the impact of the vadose zone, precipitation, aquifer media, permeability, soil media, and hydraulic conductivity. We used the slope module in ArcGIS 10.3 to convert the Digital Elevation Model (DEM) raster layer into the slope map layer used for our analysis. The pollution potential of the aquifer specifies the relative status of each of the seven parameters, and they are weighted accordingly. These parameters are not only ranked based on their impact on contamination possibility but are also subdivided into different classes and ranges. Based on their relative impact on the contamination possibility, a rating value between 1 and 9 is allocated to all parameters subclasses. A value to each parameter was allocated stretching from 1 to 5 as weight provisional to their comparative importance as given in Table 2. These ratings are based on expert judgment, extensive literature review, and methodologies adopted by $[27,39]$.

Table 1. Data sources for all the used parameters and for the validation of the model.

\begin{tabular}{|c|c|c|}
\hline 1 & Net Recharge & Rainfall Dataset of Pakistan Meteorological Department \\
\hline 2 & Aquifer media & $\begin{array}{l}\text { Soil Survey of Pakistan and Pakistan Council of Research in Water Resources } \\
\text { (PCRWR) }\end{array}$ \\
\hline 3 & Soil media & $\begin{array}{l}\text { Soil Survey of Pakistan and Pakistan Council of Research in Water Resources } \\
\text { (PCRWR) }\end{array}$ \\
\hline 4 & Topography & $\begin{array}{l}\text { Aster DEM, downloaded from } \\
\text { (https://earthexplorer.usgs.gov/) }\end{array}$ \\
\hline 5 & Impact of vadose zone & $\begin{array}{l}\text { Soil Survey of Pakistan and Pakistan Council of Research in Water Resources } \\
\text { (PCRWR) }\end{array}$ \\
\hline 6 & Hydraulic conductivity & $\begin{array}{l}\text { Soil Survey of Pakistan and Pakistan Council of Research in Water Resources } \\
\text { (PCRWR) }\end{array}$ \\
\hline 7 & Population Data & $\begin{array}{l}\text { The Gridded Population of the World, Version } 4 \text { (GPWv4), downloaded from } \\
\text { (https://sedac.ciesin.columbia.edu/data/set/gpw-v4-population-density-rev11) } \\
\text { FAO Land use Data set downloaded from }\end{array}$ \\
\hline 8 & Land Use Data & $\begin{array}{l}\text { (http://www.un-spider.org/links-and-resources/data-sources/land-cover-and- } \\
\text { land-cover-change-himalaya-region-fao) }\end{array}$ \\
\hline 9 & Nitrate Concentration & Water Well Data \\
\hline
\end{tabular}


Table 2. Classes, their ratings, and the assigned weights of DRASTIC parameters [40]

\begin{tabular}{|c|c|c|c|}
\hline Parameter & Range & Rating & Weight \\
\hline \multirow{6}{*}{ Depth to water table (m) } & $<40$ & 9 & \multirow{6}{*}{5} \\
\hline & $40-60$ & 7 & \\
\hline & $60-80$ & 5 & \\
\hline & 80-100 & 3 & \\
\hline & $>100$ & 1 & \\
\hline & $>80$ & 9 & \\
\hline \multirow[t]{2}{*}{ Net recharge $(\mathrm{mm})$} & $60-80$ & 7 & \multirow[t]{2}{*}{4} \\
\hline & $<60$ & 5 & \\
\hline \multirow[t]{2}{*}{ Aquifer media } & Sand & 8 & \multirow{3}{*}{3} \\
\hline & Sandy loam & 7 & \\
\hline \multirow{4}{*}{ Soil media } & Silt & 6 & \\
\hline & Sandy clay & 4 & \multirow{3}{*}{2} \\
\hline & Clay & 2 & \\
\hline & $<5$ & 9 & \\
\hline \multirow{4}{*}{ Topography } & $5-10$ & 8 & \multirow{4}{*}{1} \\
\hline & $10-20$ & 6 & \\
\hline & $20-40$ & 4 & \\
\hline & $>40$ & 2 & \\
\hline \multirow[t]{2}{*}{ Impact of vadose zone } & Sand & 7 & \multirow[t]{2}{*}{5} \\
\hline & $>300$ & 9 & \\
\hline \multirow{3}{*}{ Hydraulic conductivity } & $200-300$ & 8 & \multirow{3}{*}{3} \\
\hline & $100-200$ & 6 & \\
\hline & $<100$ & 4 & \\
\hline
\end{tabular}

\section{Results}

\subsection{Thematic Maps of the Parameters}

Through the DRASTIC and modified DRASTIC (DRASTICA) methodologies, seven and eight organized thematic maps were incorporated to formulate the risk maps of the earlier mentioned two approaches, respectively, corresponding to the groundwater susceptibility valuation of the study area. The sequential steps are outlined below.

\subsubsection{Depth to Water}

The gap between the water table and the land surface is the depth to the groundwater table, which plays an active role in the evaluation of a certain area's susceptibility to pollution. The depth to water is of primary importance because the distance (the stretch of the material that must be covered by a pollutant before reaching the aquifer) and the sum of time (duration throughout which the contact of the pollutant with the immediate media (aquifer or soil) is sustained) can be determined. In general, for deeper water levels the pollutants travel time increases, so the chances of diminution are greater.

In the study area, the map depicting the depth to water exhibits that the groundwater level fluctuates from depths of under 40m below the earth's surface to depths greater than $100 \mathrm{~m}$ (Figure 2a). However, the area is mostly characterized by groundwater depths from 80 to $100 \mathrm{~m}$. These depth point data were split into five classes, i.e., <40, 40-60, 60-80, 80-100, and >100 m, and were allocated the flexible ratings of 9, 7, 5, 3 and 1 (Figure 2a). Afterwards, for processing in GIS, it was converted into grid to make it raster data The interval range, weight, DRASTIC rating, and resulting index of depth to water is portrayed in Table 2. In areas where water tables are high, pollutants have shorter distances to travel before contacting the groundwater, thus making these areas more susceptible to groundwater pollution. Therefore, lower rating values indicate that the groundwater level is deeper and, therefore, less susceptible to contamination. 

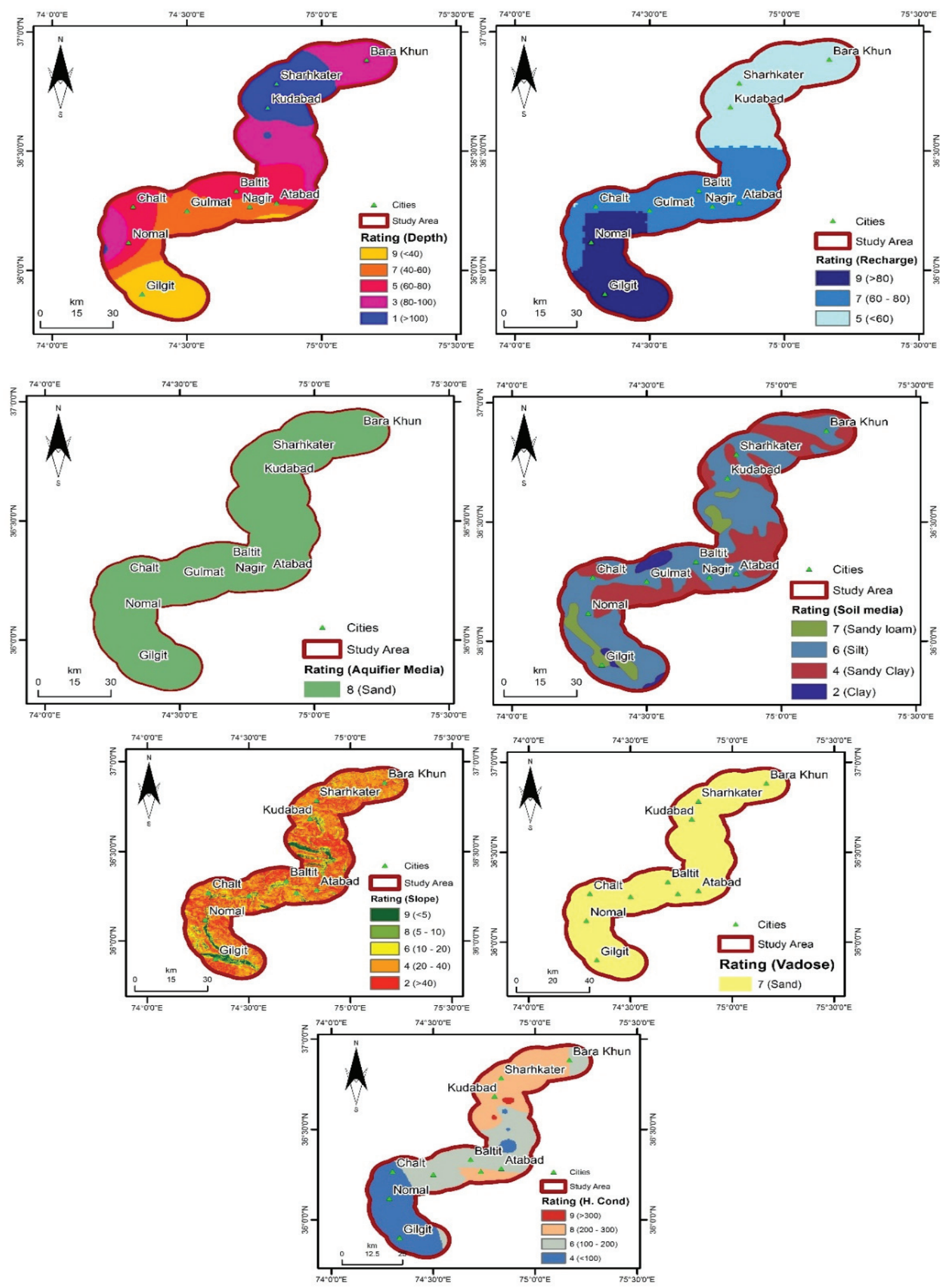

Figure 2. Seven DRASTIC thematic layers: depth to water table (a), net recharge (b), aquifer media (c), soil media (d), topography (e), the impact of vadose zone (f) and hydraulic conductivity (g).

\subsubsection{Net Recharge}

Net recharge plays a key role in the migration of pollutants, as it reflects the quantity of water that reaches the ground water table after penetration through ground surface. Water is a source of transporting the contaminants. Said migration is mostly regulated by environmental and geological 
surroundings. As the amount of water is more which is the carrier source then there is increased probability to carry contaminants.

For the perpendicular transmission of water, gravity is the influential force. Millimeter per year unit is used to define net recharge. The study area is drained through the non-perennial watercourses of the region. As monsoon season breaks in the southern range of the Himalayas, the city of Gilgit lacks substantial rainfall with an annual average of 120 to $240 \mathrm{~mm}$. Wide ranges of annual rainfall indicate variations in the weather conditions in the study area. Therefore, the annual precipitation of the study area is categorized into three classes, namely $>80 \mathrm{~mm}, 60-80 \mathrm{~mm}$, and $<60 \mathrm{~mm}$ and, thus, given the respective ratings of 9,7 , and 5 (Figure $2 b$ ).

\subsubsection{Aquifer Media}

The framework material known as media controls the flow rate (hydraulic conductivity) and the nature of an aquifer. Description of the geologic configuration, which acts as aquifer, are in case of alluvium, sand, and gravel and in case of hard rock, secondary porosities (rupture/joint) and weathered zones. High vulnerability permits more water, and, thus, more pollutants enter the aquifer. The path length and route of the contaminant are mainly controlled by the aquifer medium. Besides gradient and hydraulic conductivity, path length is a significant regulator in determining the available time for reduction progressions such as reactivity, dispersion, besides sorption, and it also determines the extent of effective surface area of constituents contacted in the aquifer. Sand is the only constituent of the aquifer media in the investigative area and is given a rating of 8 (Figure 2c).

\subsubsection{Soil Media}

The form of a surface over the unsaturated (vadose) zone can be called soil media. There is generally a variation in the thickness as we move in depth. Movement of pollutants to the vadose zone can be controlled by growing vegetables and farming activities in the soil media. Pollutants are mostly moved by recharge during the phenomenon of infiltration. The phenomenon of attenuation is determined by the form of soil media and its thickness. Five kinds of soil are found in our study area, namely, sandy loamy soil, silty soil, sandy clayey soil, and clayey soil, as presented in Figure 2d. The ratings assigned to these classes are 7, 6, 4, and 2, respectively (Figure 2d).

\subsubsection{Topography}

The gradient of the land surface along its alterations is termed as topography. In this study, we produced a topography map from ASTER DEM data. Considering the gradient values, we categorized the exploratory area into five regions; namely the region below than 5 degrees (very gentle gradient), 5-10 degrees (gentle gradient), 10-20 degrees (moderate gradient), 20-40 degrees (steep gradient), 5-10, and $>40$ degrees (very steep gradient), respectively.

Overall, the gradient progressively declines towards the south of the study area. The study area is situated in a mountainous region and is among the steepest places on Earth. The region is home to world's mightiest mountain, K2, with an elevation of $8611 \mathrm{~m}$ located on the border of Pakistan and China in the Gilgit Baltistan region of northern Pakistan. An extreme rating of 9 has been allocated to the gradient differing from approximately flat to very mild, whereas the minimum value has been allocated to the very sheer gradient (Figure 2e).

\subsubsection{The Impact of the Vadose Zone}

Between the ground surface and the water level, there is an unsaturated region known as the vadose zone. The percolating water is greatly influenced by the presence of this zone. The expanded vadose zone includes the vadose zone along with the superimposed saturated zones on the aquifer. The restraining layer is formed because of the expressively restraining zone overhead the aquifer that zone the is used as the type of media with the most substantial influence. The vadose zone of the 
pertaining area, which has been mapped as shown in Figure 2f, is comprised of sand only and is given a rating of 7 .

\subsubsection{Hydraulic Conductivity}

The water-conducting capacity of aquifer constituents is termed as hydraulic conductivity, which, for a specified hydraulic gradient, governs the groundwater's flow rate. The hydraulic conductivity values were charted, as shown in Figure 2g. The figure shows four different classes of hydraulic conductivity; namely, very high conductivity, which is characterized by a water transmission rate of more than $300 \mathrm{~m} /$ day; high conductivity with a transmission rate of 200 to $300 \mathrm{~m} /$ day; moderate conductivity with a rate of 100 to $200 \mathrm{~m} /$ day; and low conductivity with a rate of less than $100 \mathrm{~m} /$ day. These four classes were used to map hydraulic conductivity. The regions with moderate to high conductivity values have a higher availability of groundwater than those which have low conductivity values. In the study area, the DRASTIC rating was used to assign the ratings to different definite hydraulic conductivity regions.

\subsection{Preparation of DRASTIC Risk Map}

The various processes stated above were used to construct a DRASTIC model. Three susceptibility classes, namely, low, moderate, and high, are shown in the DRASTIC risk map (Figure 3) based on the DRASTIC index. The areas of Bara Khun, Sharhkater, and Khudabad showed low vulnerability (80-119), the city area of Gilgit and the region surrounding Nagar showed high vulnerability (150-180), and the remaining zones are moderately vulnerable (120-149). The DRASTIC risk map displays the combined impact of all seven constraints.

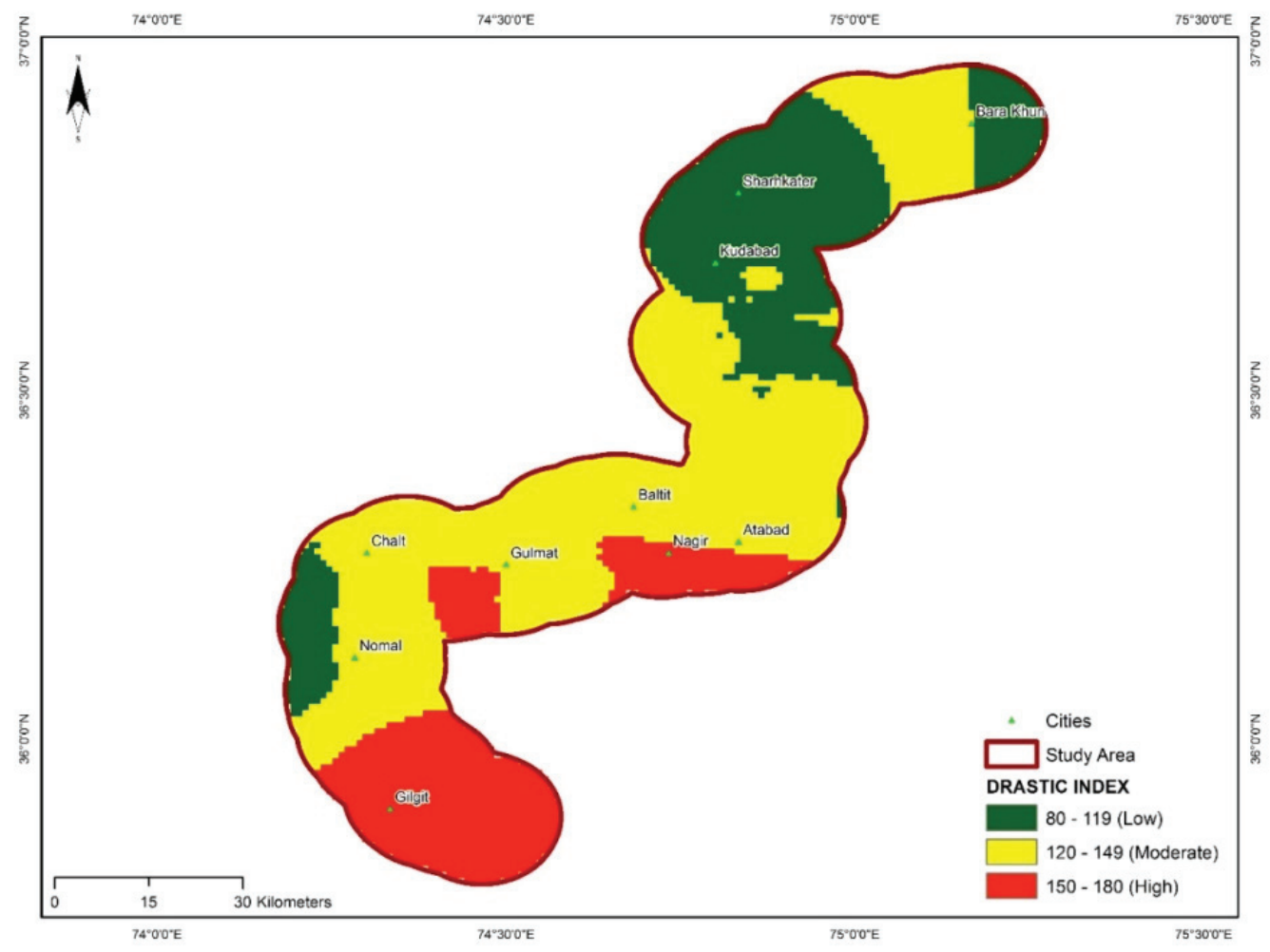

Figure 3. DRASTIC risk map of the exploratory area.

\subsection{Confines of the DRASTIC Model and Refinements}

The use of the DRASTIC model to assess groundwater susceptibility is predominant, but this model is not best suitable for a built-up environment because the anthropogenic effect is not included as a model parameter. To overcome this limitation, the current study implements an adjusted DRASTIC 
model, or DRASTICA, where the 'impact of anthropogenic activities' (represented by 'A' in the acronym) was incorporated as an additional constraint. The anthropogenic impact (A) was included in the present study by using the satellite interpretations as a supplementary parameter and land use near the built-up areas to validate the methodology.

\subsubsection{Formulation of an Anthropogenic Impact Map}

Besides the urbanization index map (developed from the University of Columbia's World Gridded Population Density dataset), a land use map of the research area was used to formulate the anthropogenic impact map.

\section{Land Use}

In most areas, the groundwater susceptibility to pollution is greatly affected by the different land use types and the activates involved in organic development. Different land use patterns like urban, commercial, industrial, and agricultural control the concentration of contaminants. The study area's land use map (Figure 4) is divided into six classes: bare areas, agriculture in the valley floor, forest, natural shrubs, snow, and water body. The land use data used in this research is acquired from the FAO land use data set. Hydrogeological parameters are notably affected by land use parameters. The sources that alter the properties of hydrogeological parameters include the addition of urban and industrial waste, use of pesticides, and seepages from septic tanks and leftover discarding spots. The area proportions listed in Table 3 show that forests cover (31\%) most of the land of the study area, as also indicated by land use division map. The subsequent most prominent land use type of the study area (29\%) are the bare lands (Table 3). The remaining land use types in the study area are divided into waterbodies, natural shrubs, snow, and agriculture in the valley floor. The susceptibility of groundwater to nitrate dilution is higher in agricultural areas. In groundwater systems, the nitrate distribution is controlled by the soil dynamics, groundwater movement, recharge rate, and on-ground nitrogen loading [5]. Urban activities and agriculture in the valley floor were found to more significantly influencing the condition of groundwater in the exploratory area than the other land use classes, as specified by the land use classification.

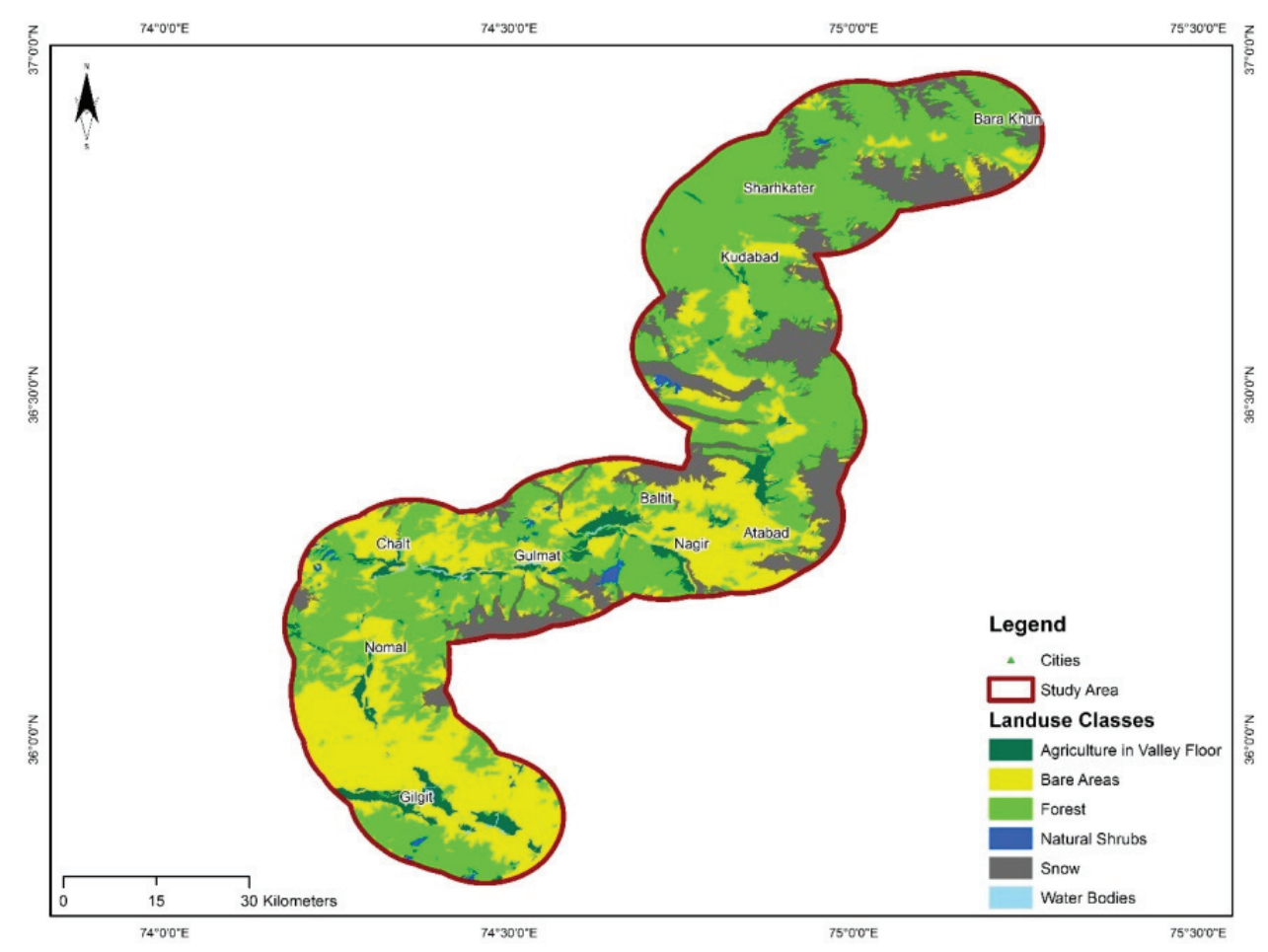

Figure 4. Land use map of the investigative area. 
Table 3. Areas of land use classes.

\begin{tabular}{cccc}
\hline Sr. No. & Land Use Classes & Area $\mathbf{k m}^{\mathbf{2}}$ & Area $\%$ \\
\hline 1 & Agriculture & 467.5 & 11 \\
2 & Bare areas & 1232.5 & 29 \\
3 & Forest & 1317.5 & 31 \\
4 & Natural shrubs & 382.5 & 9 \\
5 & Snow & 595 & 14 \\
6 & Water bodies & 255 & 6 \\
7 & Total & 4250 & $100 \%$ \\
\hline
\end{tabular}

Urbanization Index

The urbanization index map was generated using the University of Columbia's World Gridded Population Density Dataset of 2020. The urbanization index map was used for the additional enhancement of the land use map. Based on the urbanization index map (Figure 5), the urbanized class of the land use map was additionally sorted into four categories, namely, urbanized with very high density, urbanized with medium density, urbanized with low density, and urbanized with very low density. The ratings shown in Table 4 were applied to formulate the new anthropogenic map (Figure 6). The map of urbanization index was multiplied by the weight of " 5 ", which is in accordance with the weight of this parameter. An eighth parameter, termed as anthropogenic impact, was generated after integrating all these alterations and included in the DRASTIC model.

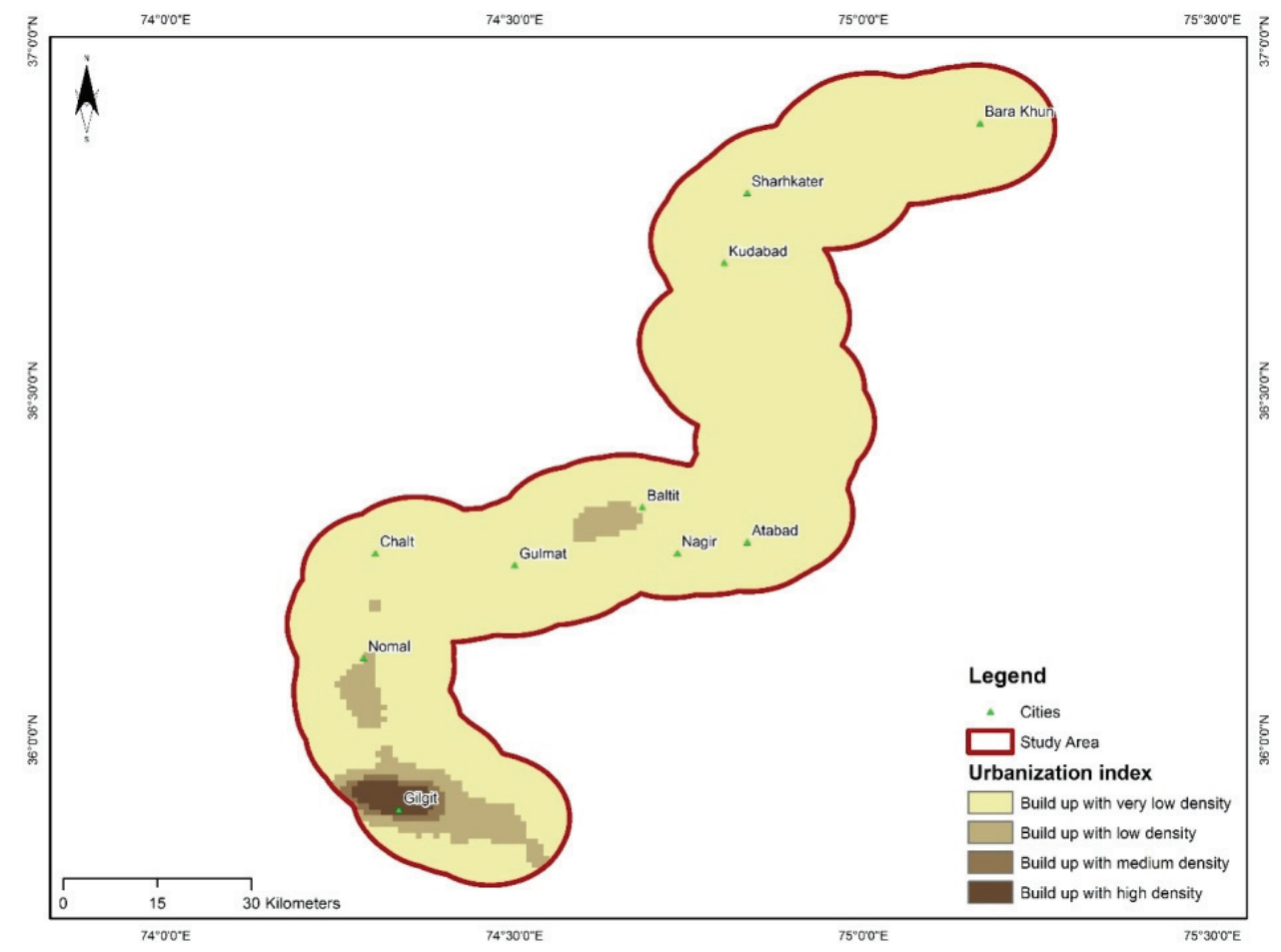

Figure 5. Urbanization index of the research area.

Table 4. Land use classes and their assigned ratings.

\begin{tabular}{cc}
\hline Land Use Classes & Ratings \\
\hline Water bodies and wastelands & 1 \\
Forest and shrubland & 2 \\
Bare areas & 3 \\
Agriculture & 5 \\
Build up with low density & 7 \\
Build up with medium density & 8 \\
Build up with high density & 9 \\
\hline
\end{tabular}




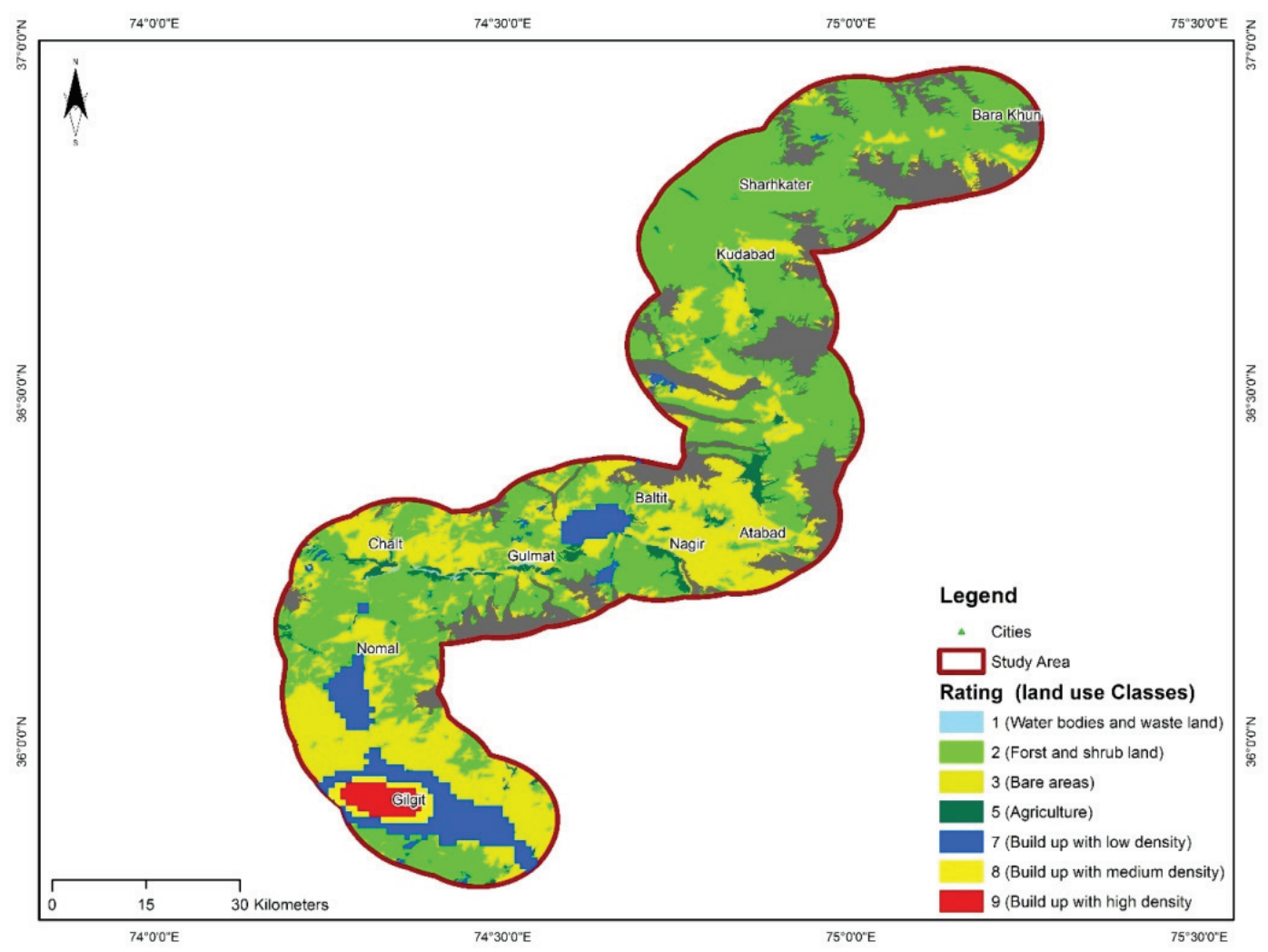

Figure 6. Anthropogenic impact map of the investigative area.

\subsubsection{Formulation of an Anthropogenic Impact Map}

In the present study, we fused anthropogenic activities with the DRASTIC map to evaluate the groundwater susceptibility to pollution. This adjusted DRASTIC model was named DRASTICA to reflect the additional parameter of anthropogenic impact. The anthropogenic impact map was transformed into raster format by multiplying the weight of the anthropogenic impact parameter $(\mathrm{Aw}=5)$ with the map. The two maps, namely, the anthropogenic impact map and the conventional DRASTIC map was overlaid to produce a spatial association among anthropogenic impact and the established DRASTIC map. The DRASTICA index, or modified DRASTIC Index (MDI), was computed using the following equation by the accumulation of ultimate grid coverage with conventional DRASTIC Index (DI) [5].

$$
\mathrm{MDI}=\mathrm{DrDw}+\mathrm{RrRw}+\mathrm{ArAw}+\mathrm{SrSw}+\mathrm{TrTw}+\mathrm{IrIw}+\mathrm{CrCw}+\mathrm{ArAw}
$$

where,

$\mathrm{Ar}=$ rate of the anthropogenic impact parameter

$\mathrm{Aw}=$ weight of the anthropogenic impact parameter

The DRASTICA map indicates which regions of the study area are extra disposed to pollutants based on the anthropogenic happenings which cause this susceptibility. The DRASICA risk map contains four susceptibility classes; namely, low (120-149), moderate (150-179), high (180-209), and very high (>210) susceptibility to groundwater contamination (Figure 7). The conducted investigation revealed that $19 \%$ of the study area falls within the very high susceptibility class, $42 \%$ is classed as having high susceptibility, $37 \%$ has moderate susceptibility, and $2 \%$ has low susceptibility to groundwater contamination. Compared to the conventional DRASTIC map, the adjusted DRASTICA map classes $15 \%$ more of the study area into the high susceptibility class (Table 5). 


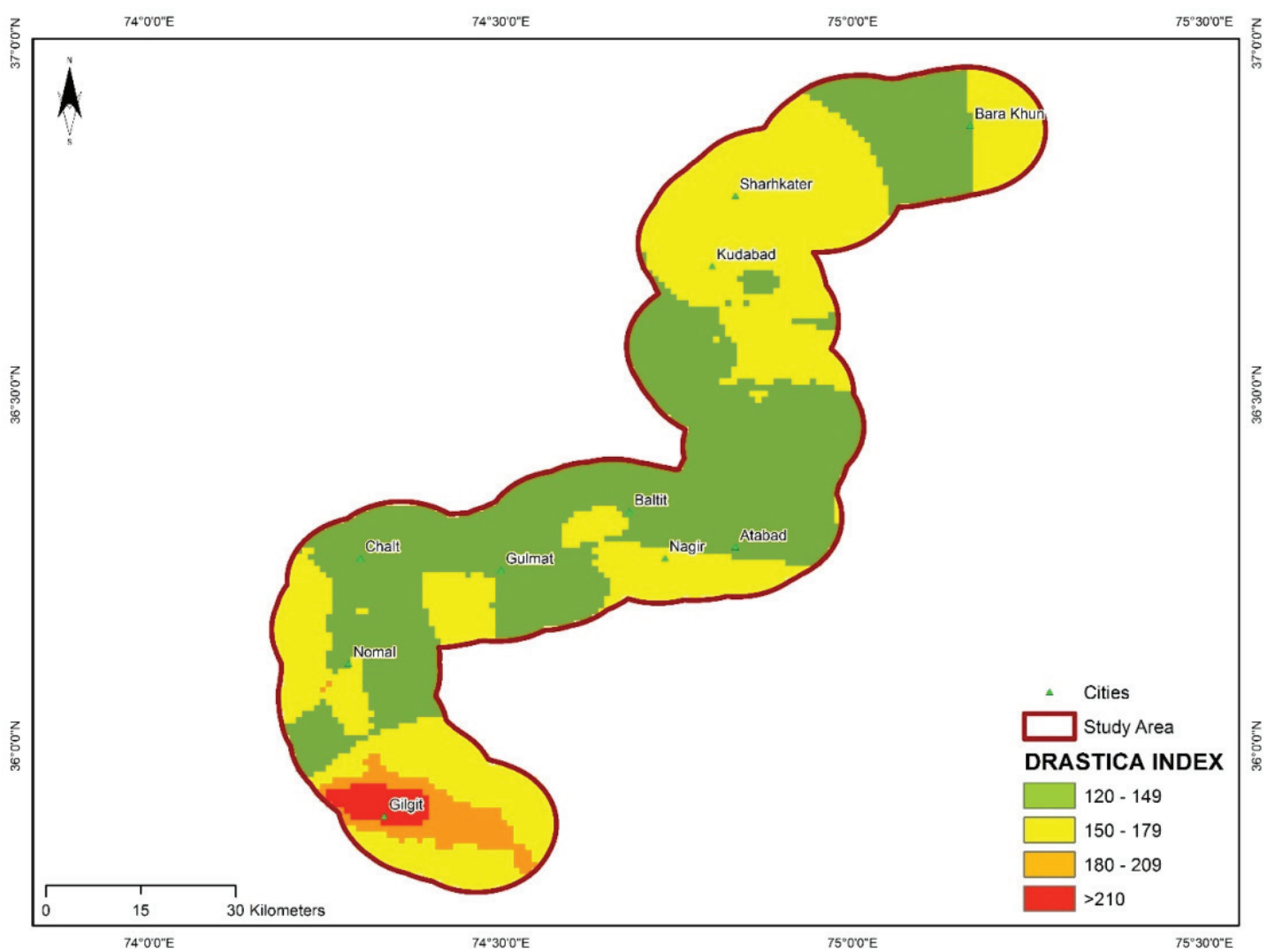

Figure 7. DRASTICA risk map of the exploratory area.

Table 5. Comparison of the DRASTIC and DRASTICA risk maps [40].

\begin{tabular}{cccccccc}
\hline \multirow{2}{*}{ Class } & \multirow{2}{*}{ Index } & \multicolumn{3}{c}{ DRASTIC } & \multicolumn{3}{c}{ DRASTICA } \\
\cline { 3 - 8 } & Ranges & N. pixel & Area km $\mathbf{~ k m}^{\mathbf{2}}$ & Area \% & N. Pixel & Area km $\mathbf{~}^{\mathbf{2}}$ & Area \% \\
\hline 1 & $<120$ & 102,000 & 1020 & 24 & 8500 & 85 & 2 \\
2 & $120-149$ & 225,250 & 2252.5 & 53 & 157,250 & 1572.5 & 37 \\
3 & $150-179$ & 89,250 & 892.5 & 21 & 178,500 & 1785 & 42 \\
4 & $>180$ & 8500 & 85 & 2 & 80,750 & 807.5 & 19 \\
\hline
\end{tabular}

\section{Discussion}

The assessment of groundwater susceptibility to contamination is vital for organizing the viable groundwater reserve, [20]. In this regard, the DRASTIC method can be used in the GIS interface for the altitudinal amalgamation of various thematic layers to evaluate groundwater susceptibility at a specific site. To analyze the groundwater susceptibility, the board of the United States Environmental Protection Agency developed diverse layers of the DRASTIC index [28,40]. The DRASTIC parameters, which are depth to groundwater-surface (D), recharge rate (R), aquifer matrix (A), soil type (S), topography (T), the impact of the vadose zone (I), and hydraulic conductivity (C), are assessed for this study area (Figure 2). The various data sources used to prepare the involved parameters are illustrated in Table 1. The depth to the water table is one of the crucial aspects determining groundwater susceptibility to pollution, as it indicates the distance that a pollutant must travel before entering an aquifer. The comparative significance of depth to water is illustrated in Table 2 [40]. In the research area, the depths to the groundwater-surface (D) vary from $9 \mathrm{~m}$ to more than $100 \mathrm{~m}$ (Figure 2a). Based on expert opinions and literature review, the depth was divided into five intervals, namely, $<40,40-60$, $60-80,80-100$, and $>100[16,41,42]$. The yearly volume of water that penetrates the aquifer after infiltrating the ground surface is termed as the Net Recharge (R) [43]. The DEM used in the preparation of the slope map and the rainfall data collected from the Pakistan Metrological Department (PMD) were 
used as input data to prepare the net recharge map. Ground slope, precipitation and soil permeability are the factors that affect net recharge [44]. Finally, the net recharge was divided into three classes: $>80$, $60-80$, and $<60$. The weightings and classes are mentioned in Table 2.

Horizontal and vertical lithological variability was addressed by classifying the lithology. Hydrogeological formation layers were generated by interpolating point data. How well a certain configuration would act as an aquifer unit was evaluated proportionally and was based on assigning the ratings (Figure 2c). The framework material that is mostly used to control the rate of flow and the nature of an aquifer is termed as media. This media also employs a foremost control over the route and the length of the path of the contaminants [9]. In general, the contaminant attenuation capacity of an aquifer hinges on the sorting and amount of fine grains, and this is what that determines the aquifer media. Thus, high susceptibility ratings are yielded based on high penetrability [45]. A high rating of 8 has been allotted to the aquifer media that contains solely sand (Figure 2c). Soil has a substantial influence on the quantity of recharge that can penetrate into the ground, and have the capability of a pollutant to move sheerly into the vadose zone [46]. Within the soil cover, the occurrence of delicate particles, such as silt, peat or clay, and the presence of carbon-based matter intrinsically reduces the soil permeability, which retards the passage of pollutants through physicochemical progressions, i.e., biodegradation, absorption, oxidation, and ionic exchange [47]. Therefore, the permeability of the different soil types was used to assign the ratings (Table 2) accordingly, with the highest ratings allotted to highly permeable soil and lower ratings to the less permeable soil, as depicted in the Figure $2 \mathrm{~d}$.

The slope of an area is determined by the topography of that area. A ground slope map was constructed using a DEM and was divided into five classes: 5, 5-10, 10-20, 20-40, and >40 degrees (Figure 2e). Water flow is reserved for increased period of time in the low gradient areas thus accounting for the bigger tendency of pollution [48]. Areas with sheer gradients are less susceptible to groundwater contamination because they have smaller amounts of infiltration due to large amounts of runoff [33]. Considering these facts, nearly flat areas with up to 5 degrees of slope were allocated a high rating value of 9 , followed by 5-10,10-20, 20-40 degrees of slope ranked 8, 6, 4, respectively, and the steepest slopes of $>40$ degrees receiving the lowest rating of 2 (Table 2). The subsurface movement of water, i.e., filtration of rainwater, is greatly influenced by the vadose zone [17,49]. In the study area, the main constituent of the vadose zone was found to be solely sand, which was assigned a rating of 7 (Table 1). The procedures that were implemented to measure and formulate the maps of constraints depth to water (D) and aquifer media (A) were comparable to the procedure carried out on lithological data to create the Impact of vadose zone (I) map. The constituent materials of the vadose zone determine the contamination exhaustion features like sorption, biodegradation, dispersion, volatilization, and biodegradation [40]. Hydraulic conductivity (C), which ranges from $<100$ to $>300 \mathrm{~m} /$ day in the study area, disturbs the passage rate of contaminants in the aquifer (Figure $2 \mathrm{~g}$ ). The groundwater is always on the move, and the capability of the aquifer to conduct water is known as hydraulic conductivity [9].

A final susceptibility map (Figure 3) was generated after the weights and ratings of each parameter were defined by operationalizing the prototype in the ArcGIS setting. The DRASTIC susceptibility index was finalized by integrating the combined influences of seven data layers using a GIS environment. Despite adopting the numerous general color coding of susceptibility maps [40], the index range was centered on the swiftly used method for susceptibility classification $[43,50,51]$. Thereby, the obtained DRASTIC susceptibility index ranged from 80 to 150 . These values were classified into the three categories of high, moderate, and low susceptibility to groundwater contamination using the quantile arrangement scheme (Figure 3). Based on this model, about $1020 \mathrm{~km}^{2}$ of the total study area, comprising $4250 \mathrm{~km}^{2}$, is classed as having low susceptibility to groundwater contamination, with a DRASTIC index of $<120$. Furthermore, around $2252.5 \mathrm{~km}^{2}$ falls within the moderate susceptibility class, with DRASTIC values ranging from 120 to 149; while a total of $892.5 \mathrm{~km}^{2}$ falls within the high susceptibility class, with DRASTIC values ranging from 150 to 179 . Lastly, $85 \mathrm{~km}^{2}$ of the total study area is classed as a very high susceptibility region, with a DRASTIC index of $>180$. The results further specify that $85 \mathrm{~km}^{2}$ (2\%) of the research area, corresponding to the urban area of Gilgit city, 
is subjected to a very high risk of contamination possibility. The reason for the city's high susceptibility to groundwater pollution may be the combined effect of the shallow water table, porous vadose zone, and gentle slope. Whereas, on the other end of the spectrum, a notable part of the study area is classed as having low contamination susceptibility and comprises the areas of Bara Khun, Sharhkater, and Khudabad. This could be credited to all the parameters that decrease the probability of the aquifer getting polluted, including a deep water table, low recharge rate, and high slope. Overall, the DRASTIC analysis indicates that a considerable portion of the research area has a reasonable susceptibility to groundwater pollution.

Most previous studies have used the conventional DRASTIC model to assess the groundwater susceptibility to pollution, whereby some researchers noted weaknesses in the model. Although this model considers the transportation of contaminants from the surface to the groundwater through the unsaturated zone, the pollution that results from humanoid actions-termed as anthropogenic effects, which lower the DRASTIC index values-are forgotten. Anthropogenic actions, such as expansion, industrialization, and agriculture, are increasing the susceptibility of groundwater reserves to pollution $[4,52,53]$. Common alterations made to the DRASTIC model in previous studies include adding or eliminating one or more of the aquifer or environmental parameters, conferring to the characteristics of the respective research objectives and study areas. The main alterations include the amendment of ratings $[17,54,55]$ and adding extra parameters $[27,56,57]$.

In this research, the conventional DRASTIC model, first proposed by Aller et al. [40], was modified to include anthropogenic effects (DRASTICA) and used to analyze the susceptibility of groundwater to pollution in a study area along the CPEC route in the region of Gilgit Baltistan, situated in northern Pakistan. The ratings and weights of the anthropogenic impact maps were assigned considering the land use class conventions $[5,23,33]$ to produce the DRASTICA risk map (Figure 7). The filed examinations of groundwater conditions are best validated using the DRASTICA risk map, which represents an improved measure of susceptibility compared to the conventional risk map. The anthropogenic activities in urban areas resulted in increased nitrate contamination. The most effective parameters that accounts for groundwater contamination include depth to the water table, hydraulic conductivity, and anthropogenic impact, while soil media, net recharge, topography, and aquifer media are the least effective parameters. The groundwater susceptibility map can be used as an early warning tool to locate the areas subjected to groundwater contamination and is thus useful for the protection, organization, and planning of groundwater resources. The DRASTICA map was sorted into four categories of susceptibility (very high, high, moderate, and low susceptibility), compared to the conventional DRASTIC risk map, which has only three classes. Due to intensified anthropogenic impact and low water level, the urban area of Gilgit is distinguished by very high susceptibility. A large proportion of the study area falls within the low susceptibility zone. Low susceptibility is observed in areas around shrubland, wasteland, forest land, and water bodies. The built-up areas show high susceptibility to contamination, and the samples collected from urban areas showed high nitrate concentrations.

Generally, the DRASTIC model is subjected to several uncertainties. For example, the classes of each parameter in the DRASTIC model are rated based on expert opinions, which is the main reason for the model's ambiguity. To verify the zonation produced by DRASTIC, the generated results are validated by comparing the susceptibility zones of the study area with the respectively present nitrate concentration. The hazard zonation mapping was fully validated with the known nitrate concentration susceptibility zones, and, afterwards, the procedure of sensitivity analysis was progressed with to check the influence of individual parameter layers on the susceptibility analysis.

\subsection{Confirmation of the Methods}

Recent groundwater contamination resulting from surface occurrences, such as inflow from city sewages and agriculture, is indicated by a high dilution of negative $\mathrm{NO} \neg 3$ in the limit of 0.4 to $318.2 \mathrm{mg} / \mathrm{L}$ [58]. The nitrate parameter of water quality was used (Figure 8 ) to validate both the 
conventional DRASTIC and novel DRASTICA procedures. In a groundwater system, there is usually no source of nitrate. Therefore, its presence in groundwater is an indication of contamination from sources like anthropogenic and agricultural activities. The data for the preparation of the nitrate concentration map was collected from previously conducted research on water quality assessment in the pertaining region [59] (Table 1). The high nitrate (negative NO3) concentration, as shown in the map, indicates that polluting sources are involved.

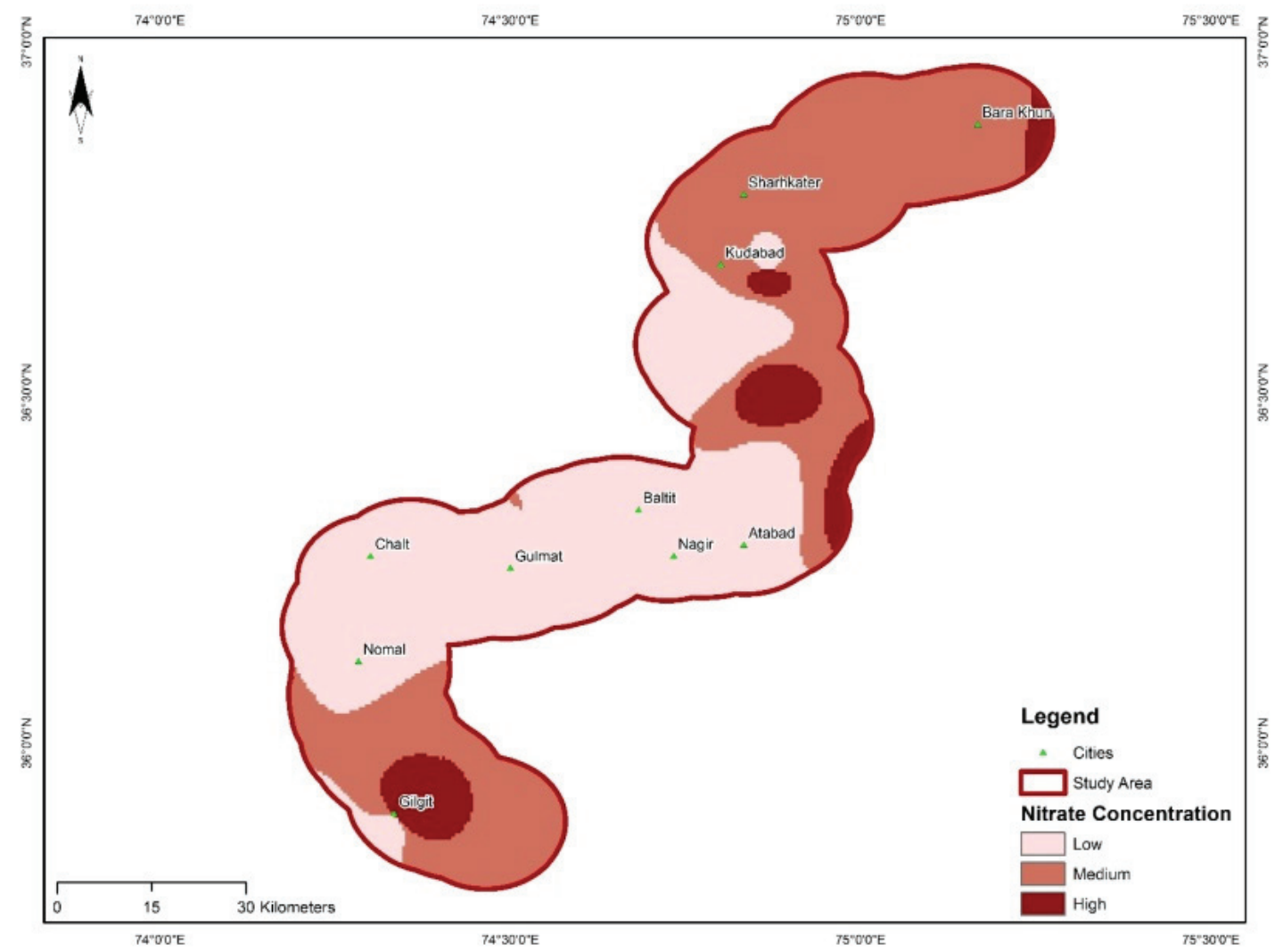

Figure 8. Nitrate concentration in the groundwater of the research area.

A correlation was detected between the estimates of DI, MDI, and nitrate concentrations. The connection between two computable and constant variables is examined through correlation [60]. In the current research, a proper relationship was portrayed between the DRASTICA index and the maximum values of nitrate concentration. A Pearson's correlation coefficient ' $r$ ' of -0.61 for DI and 0.81 for MDI was noted after these indexes were correlated with the present nitrate concentrations. The plots of 50 correlated data pairs are shown in Figures 9 and 10 for DI and MDI, respectively, against the nitrate concentrations. The additional validation of the DRASTICA model for the built-up environment is shown by the subsequent constructive correlation between nitrate concentration and MDI. 


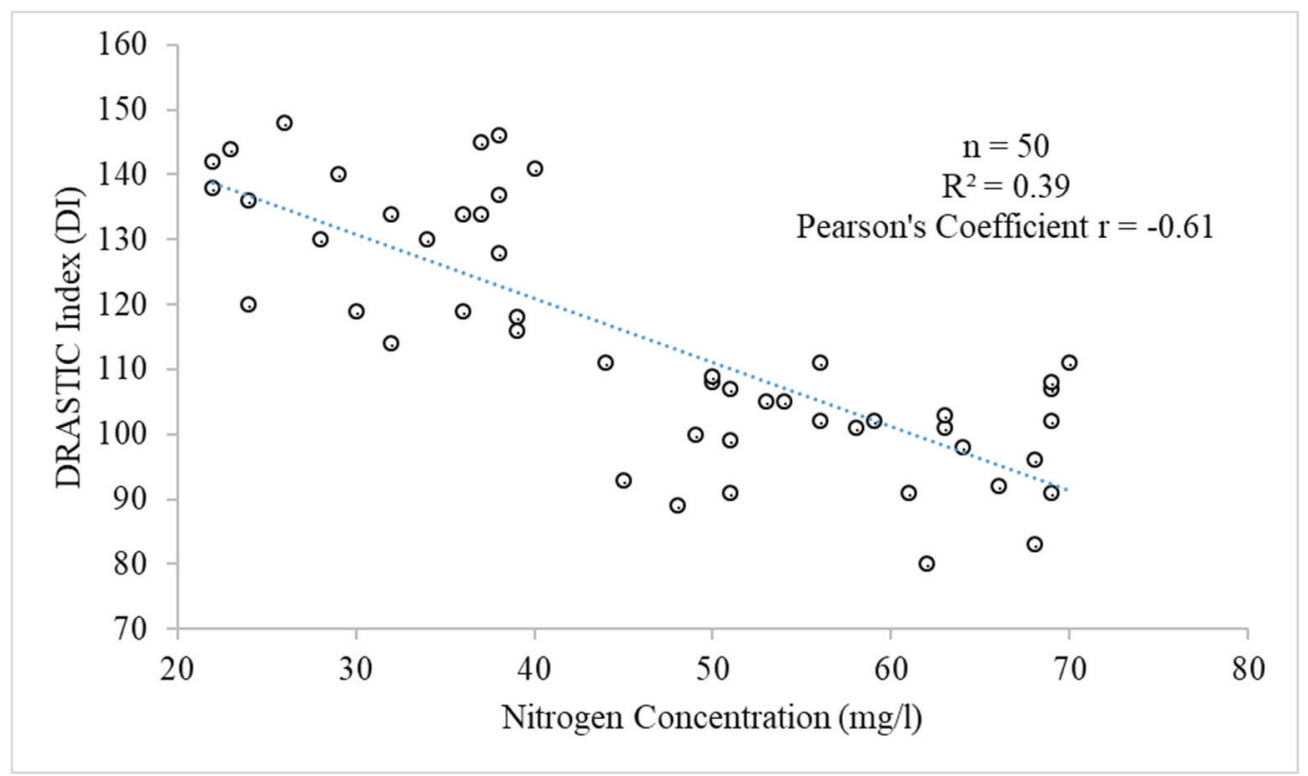

Figure 9. Plot relating nitrate concentration (mg/L) and the DRASTIC index (DI).

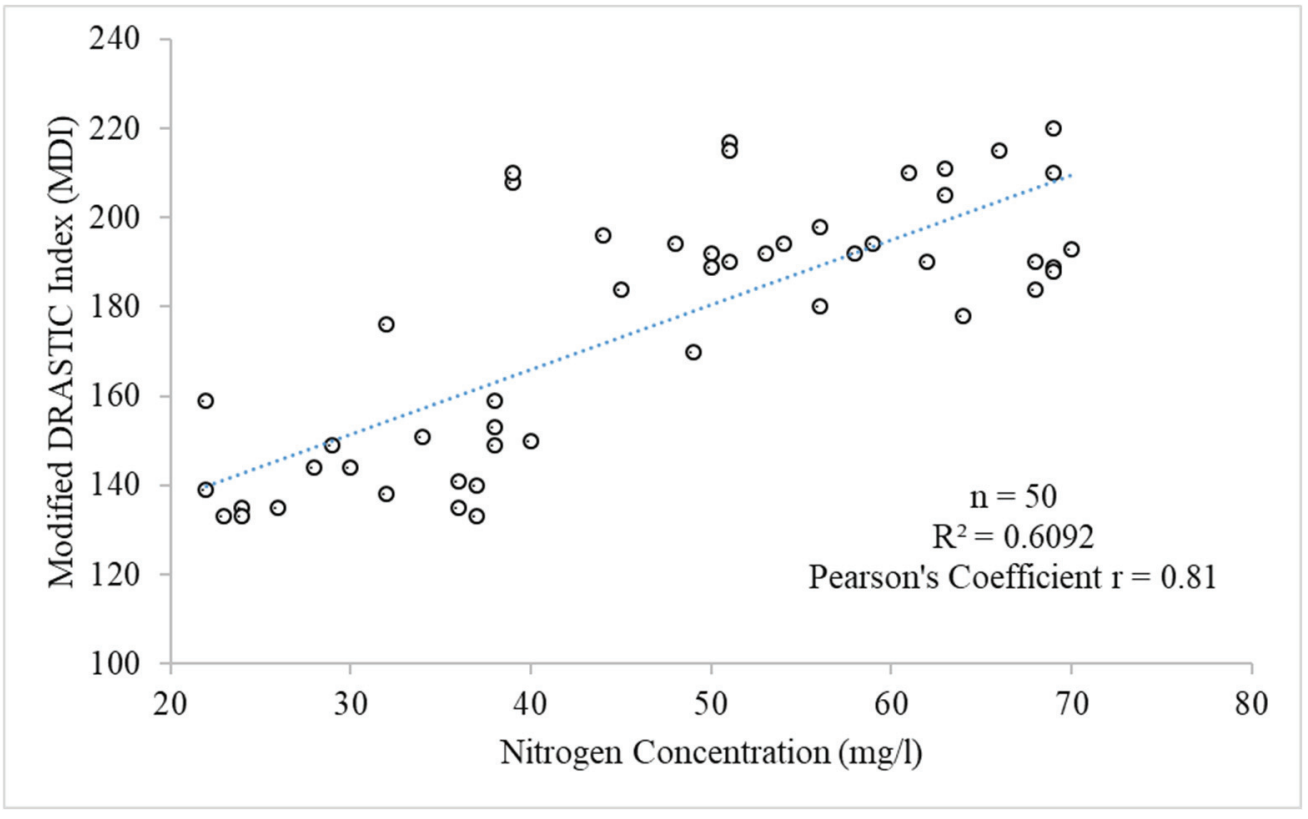

Figure 10. Plot relating nitrate concentration $(\mathrm{mg} / \mathrm{L})$ and the modified DRASTIC index (MDI)

\subsection{Sensitivity Analysis}

An effective assessment tool is the sensitivity analysis, which validated and evaluated the uniformity of the analytical results of the susceptibility maps [61]. The final output is rendered uncertain due to the impact of individual parameters [62] as in the DRASTIC model successful assessment can be achieved using an increased number of input data layers which is an important benefit [22]. However, some investigators, such as Barber et al. [63], believed that by reducing the number of input parameters the results obtained by the DRASTIC model could be improved in the manner of precision. In this study, sensitivity analysis was applied to check the accuracy of the susceptibility maps generated by the DRASTICA model. Lodwick, Monson [64] familiarized the map removal sensitivity analysis, whereas Napolitano and Fabbri [65] proposed a single parameter sensitivity analysis. In this study, the model's sensitivity analysis was conducted by performing the following two sensitivity tests. 


\subsubsection{Map Removal Sensitivity Analysis}

The map removal sensitivity method was used to eliminate one or more parameter layers of the DRASTICA index map at a time using the following equation:

$$
\mathrm{S}=\left[\left(\mathrm{V} / \mathrm{N}-\mathrm{V}^{\prime} / \mathrm{n}\right) / \mathrm{V}\right] \times 100
$$

where,

$\mathrm{S}=$ sensitivity measure

$\mathrm{V}=$ unagitated vulnerability index (all seven parameters were used to obtain the actual index)

$\mathrm{V}^{\prime}$ =agitated vulnerability index (vulnerability index computed exercising a lesser quantity of constraints)

$\mathrm{N}$ and $\mathrm{n}=$ to compute $\mathrm{V}$ and $\mathrm{V}^{\prime}$ the used number of data layers

The outcomes of the map removal sensitivity analysis after the DRASTICA parameter layers were removed one or more at a time are illustrated in Tables 6 and 7. In ArcGIS, the raster math tool was used to compute the sensitivity measure for each grid cell, according to Equation 3 . This analysis detected an increased disparity in the vulnerability index as the parameter layers of anthropogenic impact and depth to the water table (mean variation of $1.98 \%$ then $1.57 \%$ accordingly) were removed. Due to the lower variation in the ratings of soil media and topography and lesser parameter weights, after depth to the groundwater table, the deletion of the topography and soil media layers are comparatively less sensitive to the vulnerability index. The aquifer media layer is the least sensitive of all eight parameters used in the DRASTICA model, as the layer's removal result is only $0.41 \%$.

Table 6. Results of the map removal sensitivity analysis after removing each parameter.

\begin{tabular}{ccccc}
\hline \multirow{2}{*}{$\begin{array}{c}\text { Parameter } \\
\text { Removed }\end{array}$} & \multicolumn{2}{c}{ Variation } & \multicolumn{2}{c}{ Index \% } \\
\cline { 2 - 5 } & Mean & Min & Max & SD \\
\hline D & 1.57 & 1.01 & 2.5 & 0.19 \\
R & 0.62 & 0.16 & 2.08 & 0.31 \\
A & 0.41 & 0.04 & 0.92 & 0.15 \\
S & 1.13 & 0.79 & 1.42 & 0.11 \\
T & 1.33 & 1.1 & 1.6 & 0.09 \\
I & 1.12 & 0.42 & 1.5 & 0.15 \\
C & 0.7 & 0 & 1.52 & 0.26 \\
A & 1.98 & 2.1 & 2.27 & 0.21 \\
\hline
\end{tabular}

Table 7. Results of the map removal sensitivity analysis after using parameter.

\begin{tabular}{ccccc}
\hline \multirow{2}{*}{$\begin{array}{c}\text { Parameter } \\
\text { Removed }\end{array}$} & \multicolumn{2}{c}{ Variation } & \multicolumn{2}{c}{ Index\% } \\
\cline { 2 - 5 } & Mean & Min & Max & SD \\
\hline D,R,S,T,I,C,A & 0.31 & 0 & 0.79 & 0.11 \\
D,S,T,I,C,A & 0.74 & 0 & 2.3 & 0.41 \\
D,S,T,I,A & 0.59 & 0 & 2.75 & 0.46 \\
D,S,T,A & 1.56 & 0 & 3.43 & 0.61 \\
D,T,A & 1.4 & 0 & 4.1 & 0.59 \\
D,A & 11.03 & 5.67 & 15.34 & 1.34 \\
A & 9.16 & 5.67 & 13.04 & 1.2 \\
\hline
\end{tabular}

\subsubsection{Single Parameter Sensitivity Analysis}

The calculated variation index using map removal sensitivity analysis explained the importance of each involved parameter, while single parameter sensitivity analysis equates "effective" masses alongside "theoretical" masses [66]. The effect on the vulnerability index of all eight DRASTICA 
parameters was checked by performing a single parameter sensitivity test. In this test, each parameter of individual sub-area was compared in manner of their "effective" and allotted "theoretical" value.

The "effective" weight Wpi (\%) of the individual sub-area was computed using the following equation:

$$
\text { Wpi }=(\text { Pri } \times \text { Pwi } / \text { V }) \times 100
$$

where,

Wpi $=$ effective weight $(\%)$

Pri $=$ rating of individual parameter

Pwi = weight of individual parameter

$\mathrm{V}=$ ultimate susceptibility index

Although, in obtaining the DRASTICA vulnerability index, the eight used parameters were ranked using map removal sensitivity analysis the single parameter sensitivity analysis assesses the relationship between the "theoretical" and "effective" weights of parameters (Eq. 4). The deviation between "effective" and "theoretical" assessments of the DRASTICA constraints are portrayed in Table 8 . Based on the single parameter sensitivity analysis, the most significant parameters in the susceptibility valuation were anthropogenic impact (19.4\%), hydraulic conductivity (17.4\%) and depth to water table $(23.5 \%)$, as their effective weights surpass the theoretical weights assigned by DRASTICA $(18.6 \%, 14.8 \%, 22.4 \%$, respectively). The theoretical weight (5.2\%) of topography is also surpassed by its effective weight (5.9\%). For the remaining parameters, namely, net recharge, aquifer media, impact of the vadose zone, and soil media, the effective weights are lower than their assigned theoretical weights. Thus, for the parameters of hydraulic conductivity, topography, and net recharge, more comprehensive and precise data is required for the improved valuation of groundwater susceptibility.

Table 8. Results of single parameter sensitivity analysis.

\begin{tabular}{ccccccc}
\hline \multirow{2}{*}{$\begin{array}{c}\text { Parameter } \\
\text { Removed }\end{array}$} & \multirow{2}{*}{$\begin{array}{c}\text { Theoretical } \\
\text { Weight }\end{array}$} & \multirow{2}{*}{$\begin{array}{c}\text { Theoretical } \\
\text { Weight (\%) }\end{array}$} & \multicolumn{2}{c}{ Experimental } & \multicolumn{2}{c}{ Weight (\%) } \\
\cline { 4 - 7 } & & & Mean & Min & Max & SD \\
\hline D & 5 & 22.4 & 23.5 & 19.2 & 29.43 & 1.17 \\
R & 4 & 17.3 & 17.4 & 2.6 & 26.84 & 3.87 \\
A & 3 & 1.7 & 8.5 & 4.1 & 18.65 & 1.47 \\
S & 2 & 7.1 & 7.3 & 6.3 & 10.54 & 0.48 \\
T & 1 & 5.2 & 5.9 & 5.1 & 8.21 & 0.65 \\
I & 5 & 22.8 & 18.9 & 16.3 & 22 & 1.21 \\
C & 3 & 14.8 & 17.4 & 15.8 & 21.54 & 0.97 \\
A & 5 & 18.6 & 19.4 & 17.5 & 26.4 & 1.04 \\
\hline
\end{tabular}

\section{Conclusions}

In this study, we evaluated the groundwater susceptibility to pollution along the CPEC route in the northern Pakistan region of Gilgit Baltistan using an experimental index DRASTIC model in GIS software. Furthermore, we used satellite observations of the area to locate the human settlements and land use patterns to develop an advanced procedure termed as the modified DRASTIC - or DRASTICA-model. Based on the results of the conventional DRASTIC model, we distinguished the study area into three susceptibility classes, namely, high, moderate, and low susceptibility to groundwater pollution; whereas, for the adjusted DRASTICA risk map, we employed four susceptibility categories comprised of very high, high, moderate and low susceptibility to contaminants. When comparing the conventional DRASTIC model and the novel DRASTICA approach for the valuation of groundwater susceptibility in developed areas, we found the DRASTICA technique to be more certain as demonstrated by the validation of the process. This method can be replicated in other urban settings if the ratings of the hydrogeological locations are adjusted accordingly. Our results reveal that $19 \%$ of the study area falls within the very high risk class, whereas $2 \%$ of the area is classed 
as having a low-risk of groundwater contamination. The urban area of Gilgit city shows very high susceptibility, which is due to the penetrable vadose zone, high net recharge rate, and shallow water level. The groundwater susceptibility map is an utmost cost-effective tool to detect zones of potential groundwater contamination, particularly in light of the chaotic and unrestrained expansion of land and objectionable events putting groundwater conditions at stake. In this regard, DRASTIC is an effective tool to generate groundwater susceptibility maps, working in a GIS environment with an effective database. Policymakers and local authorities can use this as an operative tool in managing groundwater. Proper wastewater management policies need to be implemented, and wastewater plants must be installed to protect groundwater resources.

Author Contributions: Conceptualization, Ahsen Maqsoom and Bilal Aslam; methodology and software, Umer Khalil and Hassan Ashraf; formal analysis, Rana Faisal Tufail and Danish Farooq; writing-original draft preparation, Ahsen Maqsoom and Bilal Aslam; Funding acquisition, Thomas Blaschke; Supervision, Thomas Blaschke; Visualization, Omid Ghorbanzadeh; Writing-review \& editing, Omid Ghorbanzadeh and Thomas Blaschke; All authors read and approved the final manuscript.

Funding: This research was partly funded by the Austrian Science Fund (FWF) through the GIScience Doctoral College (DK W 1237-N23).

Acknowledgments: Thanks to COMSATS University Islamabad Wah Campus for resources. Open Access Funding by the Austrian Science Fund (FWF).

Conflicts of Interest: No conflict of interest.

\section{References}

1. Hoekstra, A.Y. Water scarcity challenges to business. Nat. Clim. Chang. 2014, 4, 318. [CrossRef]

2. Mekonnen, M.M.; Hoekstra, A.Y. Four billion people facing severe water scarcity. Sci. Adv. 2016, 2, e1500323. [CrossRef] [PubMed]

3. Qu, S.; Liang, S.; Konar, M.; Zhu, Z.; Chiu, A.S.; Jia, X.; Xu, M. Virtual water scarcity risk to the global trade system. Environ. Sci. Technol. 2018, 52, 673-683. [CrossRef]

4. Hasan, M.; Islam, A.; Hasan, M.A.; Alam, J.; Peas, M.H. Groundwater vulnerability assessment in Savar upazila of Dhaka district, Bangladesh-A GIS-based DRASTIC modeling. Groundw. Sustain. Dev. 2019. [CrossRef]

5. Shirazi, S.M.; Imran, H.M.; Akib, S.; Yusop, Z.; Harun, Z.B. Groundwater vulnerability assessment in the Melaka State of Malaysia using DRASTIC and GIS techniques. Environ. Earth Sci. 2013, 70, 2293-2304. [CrossRef]

6. Guo, Q.; Wang, Y.; Gao, X.; Ma, T. A new model (DRARCH) for assessing groundwater vulnerability to arsenic contamination at basin scale: a case study in Taiyuan basin, northern China. Environ. Geol. 2007, 52, 923-932. [CrossRef]

7. Rao, D.A.; Naik, P.K.; Jain, S.K.; Kumar, K.V.; Rao, E.D. Assessment of vulnerability zones for ground water pollution using GIS-DRASTIC-EC model: A field-based approach. J. Earth Syst. Sci. 2018, 127, 49.

8. Hussain, Y.; Satgé, F.; Hussain, M.B.; Martinez-Carvajal, H.; Bonnet, M.P.; Cárdenas-Soto, M.; Akhter, G. Performance of CMORPH, TMPA, and PERSIANN rainfall datasets over plain, mountainous, and glacial regions of Pakistan. Theor. Appl. Climatol. 2018, 131, 1119-1132. [CrossRef]

9. Saha, D.; Alam, F. Groundwater vulnerability assessment using DRASTIC and Pesticide DRASTIC models in intense agriculture area of the Gangetic plains, India. Environ. Monit. Assess. 2014, 186, 8741-8763. [CrossRef]

10. Salam, M.; Alam, M. Identification and Delineation of Turag River Basin Boundary Using Remote Sensing Techniques. J. Environ. Sci. Nat. Resour. 2014, 7, 169-175. [CrossRef]

11. Haque, E.; Reza, S.; Ahmed, R. Assessing the vulnerability of groundwater due to open pit coal mining using DRASTIC model: a case study of Phulbari Coal Mine, Bangladesh. Geosci. J. 2018, 22, 359-371. [CrossRef]

12. Pfister, S.; Koehler, A.; Hellweg, S. Assessing the environmental impacts of freshwater consumption in LCA. Environ. Sci. Technol. 2009, 43, 4098-4104. [CrossRef] [PubMed]

13. Luo, T.; Young, R.; Reig, P. Aqueduct Projected Water Stress Country Rankings; Technical Note; World Resources Institute: Washington, DC, USA, 2015. 
14. Fijani, E.; Nadiri, A.A.; Moghaddam, A.A.; Tsai, F.T.C.; Dixon, B. Optimization of DRASTIC method by supervised committee machine artificial intelligence to assess ground water vulnerability for Maragheh-Bonab plain aquifer, Iran. J. Hydrol. 2013, 503, 89-100. [CrossRef]

15. Sadeghfam, S.; Hassanzadeh, Y.; Nadiri, A.A.; Zarghami, M. Localization of groundwater vulnerability assessment using catastrophe theory. Water Resour. Manag. 2016, 30, 4585-4601. [CrossRef]

16. Khosravi, K.; Sartaj, M.; Tsai, F.T.C.; Singh, V.P.; Kazakis, N.; Melesse, A.M.; Pham, B.T. A comparison study of DRASTIC methods with various objective methods for groundwater vulnerability assessment. Sci. Total Environ. 2018, 642, 1032-1049. [CrossRef] [PubMed]

17. Rahman, A. A GIS based DRASTIC model for assessing groundwater vulnerability in shallow aquifer in Aligarh, India. Appl. Geogr. 2008, 28, 32-53. [CrossRef]

18. Jaseela, C.; Prabhakar, K.; Harikumar, P.S.P. Application of GIS and DRASTIC modeling for evaluation of groundwater vulnerability near a solid waste disposal site. Int. J. Earth Sci. 2016, 7, 558. [CrossRef]

19. Prior, J.C.; Boekhoff, J.L.; Howes, M.R.; Libra, R.D.; VanDorpe, P.E. Iowa's Groundwater Basics: A Geological Guide to the Occurence, Use, and Vulnerability of Iowa's Aquifers. 2003. Available online: http://worldcat. org/isbn/00967878616 (accessed on 21 February 2020).

20. Wang, J.; He, J.; Chen, H. Assessment of groundwater contamination risk using hazard quantification, a modified DRASTIC model and groundwater value, Beijing Plain, China. Sci. Total Environ. 2012, 432, $216-226$. [CrossRef]

21. Gad, M.; El-Hattab, M. Integration of water pollution indices and DRASTIC model for assessment of groundwater quality in El Fayoum depression, western desert, Egypt. J. Afr. Earth Sci. 2019, 158, 103554. [CrossRef]

22. Evans, B.M.; Myers, W.L. A GIS-based approach to evaluating regional groundwater pollution potential with DRASTIC. J. Soil Water Conserv. 1990, 45, 242-245.

23. Secunda, S.; Collin, M.; Melloul, A.J. Groundwater vulnerability assessment using a composite model combining DRASTIC with extensive agricultural land use in Israel's Sharon region. J. Environ. Manag. 1998, 54, 39-57. [CrossRef]

24. Hasiniaina, F.; Zhou, J.; Guoyi, L. Regional assessment of groundwater vulnerability in Tamtsag basin, Mongolia using drastic model. J. Am. Sci. 2010, 6, 65-78.

25. Farjad, B.; Shafri, H.Z.B.M.; Mohamed, T.A.; Pirasteh, S.; Wijesekara, N. Groundwater intrinsic vulnerability and risk mapping. Proc. Institut. Civil Eng. Water Manag. 2012, 165, 441-450. [CrossRef]

26. Yin, L.; Zhang, E.; Wang, X.; Wenninger, J.; Dong, J.; Guo, L.; Huang, J. A GIS-based DRASTIC model for assessing groundwater vulnerability in the Ordos Plateau, China. Environ. Earth Sci. 2013, 69, 171-185. [CrossRef]

27. Singh, A.; Srivastav, S.K.; Kumar, S.; Chakrapani, G.J. A modified-DRASTIC model (DRASTICA) for assessment of groundwater vulnerability to pollution in an urbanized environment in Lucknow, India. Environ. Earth Sci. 2015, 74, 5475-5490. [CrossRef]

28. Aller, L. DRASTIC: A Standardized System for Evaluating Ground Water Pollution Potential Using Hydrogeologic Settings; Robert S. Kerr Environmental Research Laboratory, Office of Research and Development, US Environmental Protection Agency: Washington DC, USA, 1985.

29. Hussain, Y.; Ullah, S.F.; Aslam, A.Q.; Hussain, M.B.; Akhter, G.; Martinez-Carvajal, H.E.; Satgé, F.; Ashraf, A.; Iqbal, B.; Cárdenas-Soto, M. Vulnerability assessment of an agro-stressed aquifer using a source-pathway-receptor model in GIS. MESE 2017, 3, 595-604. [CrossRef]

30. Alam, F.; Umar, R.; Ahmed, S.; Dar, F.A. A new model (DRASTIC-LU) for evaluating groundwater vulnerability in parts of central Ganga Plain, India. Arab. J. Geosci. 2014, 7, 927-937. [CrossRef]

31. Khan, M.M.A.; Umar, R.; Lateh, H. Assessment of aquifer vulnerability in parts of Indo Gangetic plain, India. Int J Phys Sci. 2010, 5, 1711-1720.

32. Ckakraborty, S.; Paul, P.; Sikdar, P. Assessing aquifer vulnerability to arsenic pollution using DRASTIC and GIS of North Bengal Plain: a case study of English Bazar Block, Malda District, West Bengal, India. J. Spat. Sci. 2007, 7.

33. Al-Adamat, R.A.; Foster, I.D.; Baban, S.M. Groundwater vulnerability and risk mapping for the Basaltic aquifer of the Azraq basin of Jordan using GIS, remote sensing and DRASTIC. Appl. Geogr. 2003, 23, 303-324. [CrossRef] 
34. Huan, H.; Wang, J.; Teng, Y. Assessment and validation of groundwater vulnerability to nitrate based on a modified DRASTIC model: a case study in Jilin City of northeast China. Sci. Total Environ. 2012, 440, 14-23. [CrossRef] [PubMed]

35. Pacheco, F.A.; Fernandes, L.F.S. The multivariate statistical structure of DRASTIC model. J. Hydrol. 2013, 476, 442-459. [CrossRef]

36. Stigter, T.; Ribeiro, L.; Dill, A.C. Evaluation of an intrinsic and a specific vulnerability assessment method in comparison with groundwater salinisation and nitrate contamination levels in two agricultural regions in the south of Portugal. Hydrogeol. J. 2006, 14, 79-99. [CrossRef]

37. Xiaoyu, W.; Bin, L.; Chuanming, M. Assessment of groundwater vulnerability by applying the modified DRASTIC model in Beihai City, China. Environ. Sci. Pollut. Res. 2018, 25, 12713-12727.

38. Masoud, M.; El Osta, M. Evaluation of groundwater vulnerability in El-Bahariya Oasis, Western Desert, Egypt, using modelling and GIS techniques: A case study. J. Earth Sys. Sci. 2016, 125, 1139-1155. [CrossRef]

39. Neshat, A.; Pradhan, B.; Pirasteh, S.; Shafri, H.Z.M. Estimating groundwater vulnerability to pollution using a modified DRASTIC model in the Kerman agricultural area, Iran. Environ. Earth Sci. 2014, 71, 3119-3131.

40. Sener, E.; Davraz, A. Assessment of groundwater vulnerability based on a modified DRASTIC model, GIS and an analytic hierarchy process (AHP) method: the case of Egirdir Lake basin (Isparta, Turkey). Hydj 2013, 21, 701-714.

41. Neshat, A.; Pradhan, B.; Dadras, M. Groundwater vulnerability assessment using an improved DRASTIC method in GIS. Resour. Conserv. Recycl. 2014, 86, 74-86. [CrossRef]

42. Neshat, A.; Pradhan, B. An integrated DRASTIC model using frequency ratio and two new hybrid methods for groundwater vulnerability assessment. Nat. Hazards 2015, 76, 543-563. [CrossRef]

43. Edet, A. An aquifer vulnerability assessment of the Benin Formation aquifer, Calabar, southeastern Nigeria, using DRASTIC and GIS approach. Environ. Earth Sci. 2014, 71, 1747-1765. [CrossRef]

44. Ouedraogo, I.; Defourny, P.; Vanclooster, M. Mapping the groundwater vulnerability for pollution at the pan African scale. Sci. Total Environ. 2016, 544, 939-953. [CrossRef]

45. Usman, D. Evaluation of Models for Assessing Groundwater Vulnerability to Pollution in Niigeria. Bayero Pure Appl. Sci. 2009, 2, 138-142.

46. Chitsazan, M.; Akhtari, Y. A GIS-based DRASTIC model for assessing aquifer vulnerability in Kherran Plain, Khuzestan, Iran. Water Resour. Manag. 2009, 23, 1137-1155. [CrossRef]

47. Al-Abadi, A.M.; Al-Shamma'a, A.M.; Aljabbari, M.H. A GIS-based DRASTIC model for assessing intrinsic groundwater vulnerability in northeastern Missan governorate, southern Iraq. Applied Water Sci. 2017, 7, 89-101. [CrossRef]

48. Ghosh, A.; Tiwari, A.K.; Das, S. A GIS based DRASTIC model for assessing groundwater vulnerability of Katri Watershed, Dhanbad, India. MESE 2015, 1, 11. [CrossRef]

49. Neh, A.V.; Ako, A.A.; Ayuk II, A.R.; Hosono, T. DRASTIC-GIS model for assessing vulnerability to pollution of the phreatic aquiferous formations in Douala-Cameroon. J. Afr. Earth Sci. 2015, 102, 180-190.

50. Ahmed, I.; Nazzal, Y.; Zaidi, F.K.; Al-Arifi, N.S.; Ghrefat, H.; Naeem, M. Hydrogeological vulnerability and pollution risk mapping of the Saq and overlying aquifers using the DRASTIC model and GIS techniques, NW Saudi Arabia. Environ. Earth Sci. 2015, 74, 1303-1318. [CrossRef]

51. Nazzal, Y.; Howari, F.M.; Iqbal, J.; Ahmed, I.; Orm, N.B.; Yousef, A. Investigating aquifer vulnerability and pollution risk employing modified DRASTIC model and GIS techniques in Liwa area, United Arab Emirates. Groundw. Sustain. Dev. 2019, 8, 567-578. [CrossRef]

52. Dimitriou, E.; Moussoulis, E. Land use change scenarios and associated groundwater impacts in a protected peri-urban area. Environ. Earth Sci. 2011, 64, 471-482. [CrossRef]

53. Khan, H.H.; Khan, A.; Ahmed, S.; Perrin, J. GIS-based impact assessment of land-use changes on groundwater quality: study from a rapidly urbanizing region of South India. Environ. Earth Sci. 2011, 63, 1289-1302. [CrossRef]

54. Hussain, Y. Hydrogeophysical Investigations and GIS Vulnerability Mapping of Kot Addu; Quaid-i-Azam University: Islamabad, Pakistan, 2014.

55. Hussain, Y.; Ullah, S.F.; Hussain, M.B.; Aslam, A.Q.; Akhter, G.; Martinez-Carvajal, H.; Cárdenas-Soto, M. Modelling the vulnerability of groundwater to contamination in an unconfined alluvial aquifer in Pakistan. Environ. Earth Sci. 2017, 76, 84. [CrossRef] 
56. Hernández-Espriú, A.; Reyna-Gutiérrez, J.A.; Sánchez-León, E.; Cabral-Cano, E.; Carrera-Hernández, J.; Martínez-Santos, P.; Macías-Medrano, S.; Falorni, G.; Colombo, D. The DRASTIC-Sg model: an extension to the DRASTIC approach for mapping groundwater vulnerability in aquifers subject to differential land subsidence, with application to Mexico City. Hydrogeol. J. 2014, 22, 1469-1485. [CrossRef]

57. Abdullah, T.; Ali, S.; Al-Ansari, N.; Knutsson, S. Groundwater vulnerability mapping using lineament density on standard DRASTIC model: case study in Halabja Saidsadiq Basin, Kurdistan Region, Iraq. Engineering 2015, 7, 644-667. [CrossRef]

58. Ahmed, I.; Nazzal, Y.; Zaidi, F.; Ahmed, I.; Nazzal, Y.; Zaidi, F. Groundwater pollution risk mapping using modified DRASTIC model in parts of Hail region of Saudi Arabia. Environ. Eng. Res. 2017, 23, 84-91. [CrossRef]

59. Zafar, M.; Ahmad, W. Water Quality Assessment and Apportionment of Northern Pakistan Using Multivariate Statistical Techniques-A Case Study. Int. J. Hydrol. 2018, 2, 00040.

60. Snedecor, G.W.; Cochran, W.G. Statistical Methods, 7th ed.; Iowa State University: Ames, IA, USA, 1980; pp. 80-86.

61. Pathak, D.R.; Hiratsuka, A.; Awata, I.; Chen, L. Groundwater vulnerability assessment in shallow aquifer of Kathmandu Valley using GIS-based DRASTIC model. Environ. Earth Sci. 2009, 57, 1569-1578. [CrossRef]

62. Rosen, L. A study of the DRASTIC methodology with emphasis on Swedish conditions. Ground Water 1994, 32, 278-285. [CrossRef]

63. Barber, C.; Bates, L.E.; Barron, R.; Allison, H. Assessment of the relative vulnerability of groundwater to pollution: a review and background paper for the conference workshop on vulnerability assessment. J. Aust. Geol. Geophys. 1993, 14, 1147-1154.

64. Lodwick, W.A.; Monson, W.; Svoboda, L. Attribute error and sensitivity analysis of map operations in geographical informations systems: suitability analysis. Int. J. Geogr. Inf. Sci. 1990, 4, 413-428. [CrossRef]

65. Napolitano, P.; Fabbri, A. Single-parameter sensitivity analysis for aquifer vulnerability assessment using DRASTIC and SINTACS. IAHS Publications-Series of Proceedings and Reports-Intern Assoc Hydrological Sciences 1996, No. 235. 1996, pp. 559-566. Available online: http://hydrologie.org/redbooks/a235/iahs_235_ 0559.pdf (accessed on 7 May 2020).

66. Babiker, I.S.; Mohamed, M.A.; Hiyama, T.; Kato, K. A GIS-based DRASTIC model for assessing aquifer vulnerability in Kakamigahara Heights, Gifu Prefecture, central Japan. Sci. Total Environ. 2005, 345, 127-140. [CrossRef] 